\title{
A High Resolution Coupled Ocean-atmosphere Simulation of the Regional Climate Over Central America
}

\author{
Vasubandhu Misra ( $\sim$ vmisra@fsu.edu ) \\ Florida State University https://orcid.org/0000-0002-1345-6280 \\ C. B. Jayasankar \\ Florida State University
}

\section{Research Article}

Keywords: High Resolution Coupled Ocean-atmosphere Simulation, spatial resolution, Regional Climate Model (RCM)

Posted Date: July 8th, 2021

DOI: https://doi.org/10.21203/rs.3.rs-595895/v1

License: (c) (i) This work is licensed under a Creative Commons Attribution 4.0 International License.

Read Full License

Version of Record: A version of this preprint was published at Climate Dynamics on January 8th, 2022. See the published version at https://doi.org/10.1007/s00382-021-06083-2. 
1 A High Resolution Coupled Ocean-Atmosphere Simulation of the Regional Climate

2

3

4

5

6

11

13

\section{Over Central America}

Vasubandhu Misra1, 2, 3, \# and C. B. Jayasankar², 3

${ }^{1}$ Department of Earth, Ocean and Atmospheric Science, Florida State University, Tallahassee, Florida, U.SA.

${ }^{2}$ Center for Ocean-Atmospheric Prediction Studies, Florida State University, Tallahassee, Florida, U.SA.

${ }^{3}$ Florida Climate Institute, Florida State University, Tallahassee, Florida, U.SA.

\# Corresponding Author Email: vmisra@fsu.edu 


\section{Abstract}

This study analyzes a relatively high resolution $(15 \mathrm{~km}$ grid spacing), regional coupled

16 ocean-atmosphere simulation configured over Central America. The simulation is forced with

17 global atmospheric and oceanic reanalysis for a period of 25 years (1986-2010). The spatial

18 resolution and the time period of the Regional Climate Model (RCM) simulation are both

19 unprecedented for the region. The highlights of the RGM simulation include the verifiable

20 seasonal cycle of mesoscale features like the low level jets, the mid-summer drought and the

21 seasonal tropical cyclone activity both in the Pacific and in the Atlantic Oceans. Similarly, the

22 seasonal cycle of the robust surface ocean currents in the eastern Pacific and the Costa Rica Dome

23 is also well captured in the RGM simulation. The RGM simulation also resolves the seasonal cycle

24 of the Panama-Colombia Gyre, the Gulf of Papagayo and the Gulf of Tehuantepec Gyre. In many

25 instances we find the RGM improves upon the global reanalysis forcing the simulation, indicating

26 the potential value of dynamic downscaling. Furthermore, the co-evolving components of the

27 atmosphere and ocean in the RGM is an added benefit to the atmosphere only and ocean only

28 global reanalysis forcing the simulation. However, the model displays significant biases that

29 manifest in precipitation, precipitable water, SST and winds which could potentially be improved. 


\section{$32 \quad 1$ Introduction}

The Central American Isthmus (CAI) is by far one of the most challenging areas for climate

34 modeling. It is a narrow strip of land, which is approximately $100 \mathrm{~km}$ wide, beset with narrow range

35 of mountains and surrounded by oceans along its eastern and western coast (Fig. 1). The isthmus

36 is periodically affected by natural threats engendered by a prolonged season of Tropical Cyclone

37 (TC) activity from both the Caribbean Sea and the eastern Pacific Ocean. For example, Hurricane

38 Mitch of 1998, devastated Honduras with over 11,000 fatalities (Morris et al. 2002). Similarly,

39 Afonso (2011) and Spencer and Urquhart (2018) indicate that there is significant human migration

40 from Central American countries to the United States as an aftermath to landfalling TCs in the

41 region. Besides TGs, the region is well known for many Low Level Jets (LLJs) that are caused by

42 gaps in the mountain ranges of Central America. These LLJ's can sometimes produce low level

43 vorticity, which in conjunction with either the Inter-Tropical Convergence Zone (ITCZ) and or

44 the prevalent monsoon trough can lead to tropical cyclogenesis in the tropical eastern Pacific

45 Ocean (Heather and Bourassa 2014).

46 Maldonado et al. (2018) suggest that apart from the intense, relatively infrequent events of

47 landfalling TGs, the higher frequency meteorological events of lower intensity can also cause severe

48 impacts in the region. For example, the synoptic disturbances emanating from the ITCZ affect the

49 Pacific side of Central America (Hidalgo et al. 2015; Quiros-Badilla and Hidalgo-Leon, 2016), the

50 rainfall production from cold surges sometimes produce extreme precipitation in the dry winter

51 and early summer climate of the north and Caribbean coast of Costa Rica and Honduras (Schultz

52 et al. 1998; Retana 2012), the westward propagation of tropical disturbances in the summer

53 (Amador et al. 2016), and the mid-summer drought (Magana et al. 1999). 
55 the east of the CAI is part of the Intra-Americas Seas (IAS). The IAS is host to the second largest

56 body of warm water $\left(\geq 28.5^{\circ} \mathrm{C}\right)$ on Earth and also hosts the second largest diabatic heating center

57 of the tropics during the boreal summer (Wang and Enfield 2001). Overlying the IAS, on the

58 Atlantic side is the North Atlantic Subtropical High (NASH), which display a distinct seasonal cycle

59 (Davis et al. 1996). The equatorward flank of the NASH comprise of the easterly trades of the

60 Atlantic, which has a strong bearing on the moisture flux into the CAI as these trade winds

61 accelerate in the Caribbean Sea to form the Caribbean LLJ (CLLJ; Amador and Magana 1999;

62 Poveda and Mesa 1999; Wang 2007; Gimeno et al. 2012; Misra et al. 2014). Similarly, in the

63 Pacific side, resides the North Pacific subtropical high, which also carries the north easterly trades

64 but away from the CAI. Xie et al. (2008) suggest that variations in the tropical Atlantic Ocean can

65 affect tropical Pacific by way of the atmospheric bridge across Central America. For example, the

66 cold phase of the Atlantic Multidecadal Oscillation is observed to reduce the amplitude of the

67 seasonal cycle over the equatorial Pacific (Timmermann et al. 2007). Similarly, Xie et al. (2008)

68 indicate that cooling of the North Atlantic SST suppresses atmospheric convection over Central

69 America and tropical eastern Pacific Ocean. Likewise, the mid-summer drought over Central

70 America observed in July-August amidst their wet season before it recovers in September is a result

71 of the variations of NASH initiated by anomalies in the north tropical Atlantic Ocean (Mapes et

72 al. 2005; Xie et al. 2008). More recently, Corrales-Suastegui (2021) suggest that the differential

73 warming between the tropical Atlantic and eastern Pacific Ocean can lead to further severity of

74 the mid-summer drought in a future climate.

75 The Costa-Rica Dome located off the west coast of Central America is the shoaling of a 76 generally strong and shallow thermocline in the region. It is a 'permanent' feature that is centered 
77 around $9^{\circ} \mathrm{N}$ and $90^{\circ} \mathrm{W}$, about $300 \mathrm{~km}$ off the Gulf of Papagayo between Costa Rica and Nicaragua

78 (Wyrtki 1964). As a result of this ridging of the thermocline, the Costa Rica Dome is a region of 79 high primary productivity as nutrients are brought up to the surface by wind mixing and upwelling 80 (King 1986). However, there is significant variability of this dome both with its location and 81 magnitude as a result of the wind variations associated with the ITCZ and the surface ocean 82 currents (Fiedler 2002). Seasonally, the Costa Rica Dome is shallower in the boreal summer-fall 83 seasons when the ITCZ is over the dome and local winds are weak. In the boreal winter season, 84 the Costa Rica Dome is deeper when the ITCZ is south of the dome and the northeasterly trades 85 are stronger. However, it may be noted that like any other tropical thermal dome, the Costa Rica 86 Dome is associated with the cyclonic turning of zonal surface currents following geostrophic 87 balance. In the case of the Costa Rica Dome, these zonal surface currents in the east Pacific are 88 the North Equatorial Counter Gurrent to the south and the North Equatorial Current to the north 89 of the dome.

90 Given this rich amalgam of atmospheric and oceanic features of Central America, we are 91 motivated to conduct a regional coupled ocean-atmosphere integration at an unprecedented 92 spatial resolution of $15 \mathrm{~km}$ grid spacing to assess the fidelity of the model in simulating distinct 93 atmospheric and oceanic features. In contrast, recent regional downscaling experiments over 94 Central America are coarser in spatial resolution and are downscaling just the atmospheric 95 component (e.g., Cavazos et al. 2019; Corrales-Suastegui et al. 2020). A coupled regional climate 96 model integration over this region was last conducted in Xie et al. (2008), which was over an 8 year 97 period at $0.5^{\circ}$ grid spacing. In this study, the regional climate model integration is conducted by 98 forcing at the lateral boundaries with global atmospheric and oceanic reanalysis for a period of 25 99 years from 1986-2010. In the following section we describe the regional climate model. In Section 
3, we discuss the details of the model integration along with the validation datasets used in the study. We present the results in Section 4 followed by concluding remarks in Section 5.

\section{Model Description}

The model used for this study is the Regional Spectral Model-Regional Ocean Modeling

105 System (RSM-ROMS). RSM-ROMS is a regional, coupled ocean-atmosphere model that has 106 been extensively used for regional climate modeling studies (Li et al. 2014; Li and Misra 2014; 107 Ham et al. 2016; Misra et al. 2018). The atmospheric component of RSM-ROMS is RSM that 108 was first introduced in Juang and Kanamitsu (1994). RSM uses the spectral method to compute 109 advective derivatives using sine and cosine functions in two dimensions with wall boundary 110 conditions (Tatsumi 1986). RSM uses the semi-implicit time integration scheme. The RSM has 11128 terrain following sigma levels, with irregular spacing in the vertical that is identical to the NCEP-

112 DOE reanalysis (R2; Kanamitsu et al. 2002), and the top of the atmosphere in RSM is at 113 approximately at $2 \mathrm{hPa}$. The physics package used in RSM for this study is outlined in Table 1.

114 The scale selective bias correction(Kanamaru and Kanamitsu 2007, Kanamitsu et al. 2010) is used 115 to prevent synoptic scale drift during the integration of RSM. Additionally, we have also increased 116 the width of the sponge zone from the 8 grid points around the lateral boundaries used in the 117 previous studies (e.g., Misra et al. 2018) to 16 grid points in this study. This was done after extensive 118 model integrations, which showed that RSM displayed the most skill in reproducing the observed 119 climate at a sponge width of 16 grid points (not shown).

120 ROMS is the oceanic component of RSM-ROMS. ROMS is a free surface, terrain 121 following primitive equation ocean model (Haidvogel et al. 2000; Shchepetkin and McWilliams 122 2005). The equations are solved using the split explicit time-stepping scheme. The primitive 123 equations are discretized in the vertical by using stretched, terrain following coordinates with 30 
124 levels. The ROMS contain several subgrid scale parameterizations, which include local closure

125 schemes based on the level 2.5 turbulent kinetic energy equations (Mellor and Yamada, 1982) and

126 generic length-scale parameterization following Umlauf and Burchard (2003). For this study, we

127 used the second order biharmonic horizontal diffusion in ROMS (Ezer et al. 2002). The nonlocal

128 closure scheme is based on the $\mathrm{K}$ profile, boundary layer formulation developed by Large et al.

129 (1994). The K profile scheme has been expanded to include both surface and bottom oceanic

130 boundary layers.

RSM and ROMS are coupled with a coupling interval of 1-hour. The resolution of RSM

132 and ROMS for this study is set at $15 \mathrm{~km}$ and is identical for both model components. Therefore,

133 no flux coupler is used, and the atmospheric fluxes and SST are exchanged directly without any

134 interpolation between the two model components at every hour of the model integration.

135 Furthermore, there is no flux correction used in the model integration of RSM-ROMS.

\section{Design of Experiment}

The model domain used for this study is shown in Fig. 1. As mentioned earlier, the

139 horizontal grid spacing of RSM-ROMS is $15 \mathrm{~km}$ with the center of the grid at $85^{\circ} \mathrm{W}$ and $10^{\circ} \mathrm{N}$

140 with 149 and 178 grid points in the zonal and meridional directions, respectively. The model

141 domain extends from $3.49^{\circ} \mathrm{S}$ to $23.29^{\circ} \mathrm{N}$ and $68.01^{\circ} \mathrm{W}$ to $96.37^{\circ} \mathrm{W}$, which includes the sponge

142 zone. The orography used in RSM is interpolated to the domain grid from the Global 30 Arc-

143 Second Elevation (Danielson and Gesch 2010), which equates to a resolution of approximately

$1441 \mathrm{~km}$ (Webster et al. 2003). Similarly, the ocean bathymetry used in ROMS is from 2-minute

145 gridded global relief data from NOAA National Geophysical Data Center (2006). The orography

146 over land and the bathymetry in the ocean for the model domain and resolution is shown in Fig. 
147 1. Over land, the post-processed topography used in RSM-ROMS does not resolve the Cordillera

148 Central Mountain ranges of Costa Rica and Panama and underestimates the elevation of the Sierra

149 Madre range over southern Mexico and Guatemala. The orography is spectrally filtered to reduce

150 the grid scale numerical noise in RSM-ROMS, which we hope to rectify in our future studies over 151 this region.

152 The initial and lateral boundary conditions of the atmosphere are supplied to RSM from

153 R2. The lateral boundary conditions of RSM are provided at intervals of 6 hours. The ocean initial

154 and lateral boundary conditions are provided from Simple Ocean Data Assimilation version 2. 2.

1554 (SODA; Carton and Giese 2008). RSM-ROMS is integrated from $1^{\text {st }}$ January 1986 through $31^{\text {st }}$

156 December 2010.

The model verification and analysis are conducted in a domain that emphasizes the CAI.

158 Therefore, the regional domain over which the model results are analyzed is limited to $0^{\circ}-22^{\circ} \mathrm{N}$

159 and $75^{\circ} \mathrm{W}-95^{\circ} \mathrm{W}$. In order to verify the RSM-ROMS integration we make use of the daily rainfall

160 data from the Integrated Multi-satellitE Retrievals for Global Precipitation Mission version 6

161 (IMERG; Huffman et al. 2019). This rainfall data is available globally at $0.1^{\circ}$ grid spacing from 01

162 June 2000 to the present. Although, this data set does not overlap with the integration period of 163 RSM-ROMS (1986-2010), it still provides us a robust 20 year climatology covering both land and

164 the oceans at a resolution that is comparable to RSM-ROMS. In addition, we use the Climate

165 Prediction Center (CPG) daily rainfall data following Xie et al. 2007 and Chen et al. 2008. This

166 rainfall data is available only over land and from 1979 to the present (which overlaps with the

167 integration period of RSM-ROMS) and is at $0.5^{\circ}$ grid spacing. We also make use of the total

168 precipitable water from the NASA Water Vapor Project (NVAP;

169 https://eosweb.larc.nasa.gov/sites/default/files/project/nvap/readme/ASDG_NVAP_Overvie 
171 verify the precipitable water from the RSM-ROMS integration. The NVAP dataset is available

172 globally from 1988 to 2009 at $1^{\circ}$ grid spacing. For the verification of the model simulated SST,

173 the NOAA optimally interpolated SST dataset is used. This dataset is available from 1981 to the

174 present at $0.25^{\circ}$ grid spacing at daily interval. The Climate Forecast System Reanalysis (CFSR;

175 Saha et al. 2010) data is used for the validation of the upper air simulations. CFSR is available

176 globally at $0.5^{\circ}$ grid spacing on 17 mandatory pressure levels. We also verify the upper ocean heat

177 content measured as the depth of the $20^{\circ} \mathrm{C}$ isotherm and the wind stress from the model simulation

178 against the SODA reanalysis data (Carton and Giese 2008). The best track data of TCs both in

179 the Caribbean Sea and in the eastern Pacific Ocean from the model simulation are verified against

180 HURDAT2 (Landsea and Franklin 2013). However, the tracks of the TCis are plotted from both

181 these datasets at one-day interval as some of the variables required to track them (mean sea level

182 pressure, winds at $850 \mathrm{hPa}$, topography height, $400 \mathrm{hPa}$ temperature) following the tracking

183 algorithm of Ullrich and Zarzycki (2017) were unfortunately stored at one day interval in RSM-

184 ROMS.

185

$186 \quad 4$ Results

187 a) The Seasonal Gycle of Rainfall

188

The seasonal cycle of the observed rainfall shows distinct dry (Figs. 2a and b) and wet (Figs.

189 2c and d) halves of the year over the CAI, coinciding with the boreal winter/spring and 190 summer/fall seasons, respectively. The Inter-Tropical Convergence Zone (ITCZ) over 191 northeastern Pacific Ocean appears very strong in June-July-August (JJA; Fig. 2c), which also 192 coincides with the seasonal peak of rainfall over the CAI. The corresponding seasonal cycle of the 
193 rainfall from RSM-ROMS is shown in Figs. 2e-h and its systematic errors in Figs. 2i-l and Table

194 2. From these model figures and Table 2, we observe that although RSM-ROMS shows the 195 seasonal peak of the ITCZ in the JJA season (Fig. 2g), it underestimates the seasonal ITCZ rainfall 196 in the spring (Fig. 2j), summer (Fig. 2k), and fall (Fig. 2l) seasons while overestimating in the winter 197 season (Fig. 2i). However, the seasonal variability in the latitudinal width of the near rain free zone 198 over the eastern Pacific cold tongue region is nicely replicated in RSM-ROMS. Over the 199 Caribbean Sea, RSM-ROMS systematically overestimates (Figs. 2i-k) except in the September200 October-November (SON) season, when the model shows underestimation along the Caribbean 201 coast of Central America (Fig. 2k; Table 2).

202

Over land, RSM-ROMS uniformly overestimates across CAI in the December-January203 February (DJF) season (Figs. 2e and i, and Table 2). The systematic errors in DJF over Honduras 204 and Nicaragua and over northwestern Colombia are however significantly larger (Figs. 2e and i). 205 In the March-April-May (MAM) season, the systematic errors of rainfall from RSM-ROMS over 206 the CAI is significantly reduced (Figs. 2f and j, and Table 2). The systematic seasonal mean JJA 207 rainfall errors of RSM-ROMS over the CAI are underestimated north of Costa Rica while over 208 Panama and Costa Rica it is highly overestimated (Figs. 2g and k, and Table 2). However, in the 209 SON season, the systematic errors of rainfall from RSM-ROMS become much larger compared 210 to JJA with negative bias (underestimation) north of Panama and positive bias (overestimation) 211 south of Costa Rica (Figs. 2h and i, Table 2).

212

\section{3 b) The Seasonal Gycle of Precipitable Water}

The observed seasonal cycle of the precipitable water (Figs. 3a-d) closely follows that of

215 rainfall (Figs. 2a-d), which is well depicted in the RSM-ROMS simulation (Figs. 3e-h). The north216 south gradient of precipitable water across the domain throughout the year is quite similar in both 
217 observations (Figs. 3a-d) and RSM-ROMS (Figs. 3e-h). Furthermore, the maxima of the

218 precipitable water in the ITCZ region of the eastern Pacific throughout the year is also captured

219 in the RSM-ROMS simulation. However, over the tropical Pacific the bias in RSM-ROMS is

220 negative throughout the year (Figs. 3i-l; Table 3). A widespread dry bias of the atmospheric column

221 develops across the domain in JJA (Fig. 3k; Table 3) and SON (Fig. 31; Table 3) seasons.

222

223 c) The Seasonal Gycle of SST

224

The observed SST in Figs. 4a-d show a robust seasonal cycle in both the eastern Pacific

225 Ocean and in the Atlantic Ocean. For example, the coastal oceans of Central America both along

226 the Pacific and the Atlantic sides exhibit coldest SST in DJF (Fig. 4a) and warmest SST in JJA (Fig.

227 4c). Furthermore, the cold tongue in the eastern equatorial Pacific Ocean widens and becomes

228 colder in the JJA (Fig. 4c) and in the SON (Fig. 4d) seasons relative to DJF (Fig. 4a) and MAM (Fig.

2294 b) seasons. This seasonal cycle of the SST is reasonably captured in the RSM-ROMS simulation

230 (Figs. 4e-h). The systematic errors of SST (Figs. 4i-l) indicate that the errors are least in DJF (Fig.

$2314 \mathrm{i}$ ) and most severe in JJA (Fig. 4k) and SON (Fig. 4l) seasons. In general, the RSM-ROMS

232 simulation is dominated by warm bias over both the Caribbean Sea and in the Pacific Ocean

233 except in the cold tongue region where it exhibits a cold bias throughout the year.

234

An iconic feature of the region is the Costa Rica Dome, which shoals from west to east

235 between the westward North Equatorial Current (NEG) to the north and the eastward North

236 Equatorial Counter Current (NEGG) to the south with the Costa Rican Counter Current (CRGG)

237 along its eastern boundary (Fig. 5). This is observed in the SODA reanalysis monthly climatology

238 from the depth of the $20^{\circ} \mathrm{C}$ isotherm (a proxy for the depth of the thermocline; Fiedler 2002), with

239 the dome appearing in the Gulf of Papagayo in January-March, moving offshore during April-

240 July, intensifying in July-November, before it begins to diminish in December-January (Fig. 5). 
241 This seasonal cycle of the Costa Rica Dome is also depicted in RSM-ROMS (Fig. 6). However,

242 RSM-ROMS displays a shallower thermocline depth and weaker surface ocean currents

243 throughout the year over this region of the Pacific Ocean. Furthermore, SODA reanalysis displays

244 an anticyclonic gyre between the Gulf of Papagayo and Gulf of Tehuantepec far more strongly in

245 the winter months (Jan-Feb-Mar) than in RSM-ROMS. Perez et al. (2000) using two years of sea

246 surface temperature data, remotely sensed altimetry, and scatterometer based wind stress datasets

247 identified warm gyres forming in the winter months in this region. These gyres form as a result of

248 the seasonal peak in strong off-shore low-level atmospheric gap winds in the Sierra Madre ranges

249 that create anticyclonic wind stress curl producing warm core gyre in the region (Perez et al. 2000;

250 Kessler 2006).

251

This bias of RSM-ROMS in the evolution of the Costa Rica Dome is also observed in the

252 surface ocean currents. For example, the westward flowing SEG is much stronger and anchored

253 closer to the equator in RSM-ROMS (Fig. 6) compared to SODA (Fig. 5) throughout the year.

254 However, the seasonal cycle of eastward flowing NECG is far more reasonable in the RSM-ROMS

255 simulation with its peak around $5^{\circ} \mathrm{N}$ in October and its nadir in March. The westward flowing

256 NEG appears strong at $\sim 10^{\circ} \mathrm{N}$ from January through April and then shifts further north and

257 weakens slightly till October before the NEG begins to shift southward and strengthen (Fig. 5).

258 The RSM-ROMS simulation in Fig. 6 shows the NEC at its peak around $10^{\circ} \mathrm{N}$ from January

259 through April but then fades away till it begins to reappear in November. This bias has implications

260 on the Costa Rica Counter Current in RSM-ROMS, as this current disappears from April to June

261 before it begins to reappear as northwestward flow in July, which is unlike SODA reanalysis.

262 The upper ocean circulation in the Caribbean Sea is dominated by the Caribbean Current

263 (Fig. 5). This is a warm, persistent surface current that flows along the northern coast of South 
264 America and then along the eastern coast of Central America. Another surface ocean feature of

265 note in the Caribbean Sea is the highly variable Panama-Colombia Gyre over the Colombian

266 Basin. At the resolution of SODA reanalysis (at $0.5^{\circ}$ ), this gyre is barely resolved and is most

267 apparent in July-August-September-October season (Fig. 5). The climatological surface ocean

268 circulation in RSM-ROMS in Fig. 6 shows the persistent Caribbean Current in the northern

269 Colombian Basin, western Cayman and Yucatan Basin and a rather strong cyclonic recirculation

270 associated with Panama-Colombian Gyre in southwestern Caribbean Sea. The seasonal variation

271 of the Panama-Colombian Gyre in RSM-ROMS with intense cyclone in the boreal winter months

272 to multiple cyclones of similar size embedded in a larger but weaker cyclonic circulation in the

273 Caribbean Sea is in qualitative agreement with previous observational findings (Andrade and

274 Barton 2000; Fratantoni 2001). The depth of the thermocline in the Caribbean Sea is, however,

275 consistently shallower in RSM-ROMS (Fig. 6) compared to that in SODA reanalysis (Fig. 5). The

276 warm SST bias of RSM-ROMS both in the Caribbean Sea and eastern Pacific Ocean in Fig. 3,

277 combined with the shallower thermocline depth (Fig. 6), especially in the summer and fall seasons

278 suggests that the upper ocean is highly stratified. In other words, RSM-ROMS could benefit from

279 stronger mixing in the upper ocean to reduce some of its bias both in the Caribbean Sea and in

280 tropical Pacific Ocean.

281

282

c) The seasonal cycle of the low level jets

283

One of the grand challenges of modeling the climate of this region are the multitude of

284 LLJs that have significant implication on the hydroclimate of the region. In this regard, the

285 regional domain of the RSM-ROMS includes four prominent LLJs: The Caribbean Low Level Jet

286 (CLLJ), the Panama Low Level Jet (PLLJ), the Papagayo Low Level Jet (PaLLJ), and the

287 Tehuantepec Low Level Jet (TLLJ). The climatology of the 925hPa wind field created from both 
the CFSR and the RSM-ROMS integration are shown in Fig. 7. We will discuss the winds from

289 R2 shown in Fig. 7 in sub-section g. All of these LLJs are apparent in the CFSR annual mean 290 climatology of the 925hPa wind from their distinct maxima in the wind speed (Fig. 7b). In contrast, 291 in the annual mean climatology of the 925hPa winds of the RSM-ROMS simulation, amongst the 292 four LLJs, the CLLJ and the PaLLJ are most prominent (Fig. 7c). The PLLJ in the RSM-ROMS 293 appears subtly with a weaker wind maximum while the TLLJ does not appear as distinct (Fig. 7c). 294 The annual mean systematic errors in Fig. 7d show that the RSM-ROMS clearly underestimate 295 all of these LLJs relative to CFSR.

296 We observe in Figs. 7e-h that overall, the RSM-ROMS is able to fairly capture the seasonal 297 cycle of the four LLJs. For example, the dual maximum of the CLLJ with primary and secondary 298 peak in the boreal summer and winter is reasonably captured by the RSM-ROMS simulation (Fig. 299 7e). Although, RSM-ROMS underestimates the magnitude of the CLLJ throughout the year 300 except in September (Fig. 7e). Likewise, the PLLJ shows a dual maximum, with primary peak in 301 January and secondary peak in July, which the RSM-ROMS is able to simulate (Fig. 7f). PaLLJ in 302 Fig. 7g, shows that it peaks in February in CFSR. RSM-ROMS displays significant month-to303 month variability, although, the magnitude of PaLLJ is comparable to that of CFSR with slight 304 underestimation of the seasonal peak in February. GFSR indicates that the TLLJ reaches its annual 305 peak in November with a secondary maximum in July. The RSM-ROMS shows a similar feature 306 with a primary peak in December and secondary peak in July (Fig. 7h). But the TLLJ is 307 underestimated by RSM-ROMS relative to CFSR throughout the year (Fig. 7h).

\section{d) Interannual variability}

The interannual variations of precipitation in CAI is largely dictated by the variability of

311 the LLJs (Duran-Quesada et al. 2017). Amongst the LLJs, the internannual variations of the CLLJ 
312 during the JJA season dictate to a large extent the interannual variability of the summer

313 hydroclimate over CAI (Wang et al. 2007, 2008; Misra et al. 2014). This variation of the CLLJ is

314 associated with the variations of the Atlantic warm pool in the IAS (Wang et al. 2007, 2008), the

315 variations of the meridional pressure gradient across the Caribbean Basin modulated by the 316 tropical Pacific variability (Munoz et al. 2008) and the zonal gradient of SST between the tropical

317 Atlantic and eastern Pacific Oceans (Enfield and Alfaro 1999). In the winter although, CLLJ has a

318 seasonal peak, it does not serve as large of a source of moisture to CAI as in the summer, since the

319 associated moisture flux vectors are comparatively weaker (Munoz et al. 2008). Furthermore,

320 Maldonado et al. (2018) suggest that in the winter, moisture convergence in CAI is less important

321 to dictate the hydroclimate than during the rest of the year. In Fig. 8a we show the CLLJ index ${ }^{1}$

322 time series from CFSR and RSM-ROMS for the JJA season. The years of high and low CLLJ

323 index are highlighted in Fig. 8a. These high and low index seasons are chosen if the CLLJ index

324 exceeds or is less than the corresponding seasonal climatological mean by $0.75 \times$ standard

325 deviation. The fractional coefficient of 0.75 was chosen to achieve reasonable sample of seasons

326 for high and low index seasons to conduct a meaningful statistical significance test on the

327 corresponding precipitation anomalies. The GLLJ index in JJA season shows far higher variability

328 in RSM-ROMS than CFSR (Fig. 8a). The variations of the time series of the CLLJ index between

329 CFSR and RSM-ROMS in Fig. 8a are understandably inconsistent with each other (meaning high

330 and low index seasons are not coinciding between CFSR and RSM-ROMS) for a number of

331 reasons. These include the notion that climate simulation is not an initial value problem,

332 contributions of the bias (e.g., in SST, sea level pressure gradients that dictate the variability of

333 low-level winds) and internal variability in RSM-ROMS. Furthermore, the bias and variations in

\footnotetext{
${ }^{1}$ defined as area averaged $925 \mathrm{hPa}$ wind magnitude over $12.5^{\circ} \mathrm{N}-17.5^{\circ} \mathrm{N}$ and $76^{\circ} \mathrm{W}-80^{\circ} \mathrm{W}$
} 
334 the R2 reanalysis that is forcing the RSM-ROMS may also contribute to the inconsistencies in the 335 variations of the CLLJ between RSM-ROMS and CFSR in Fig. 8a.

336 The composite difference of JJA seasonal mean rainfall between the high and the low CLLJ

337 index years shown in Fig. 8b from CPC rainfall indicate that most of CAI has a dry anomaly, 338 consistent with the moisture flowing across the Isthmus into eastern Pacific to feed the ITCZ when 339 the CLLJ is comparatively strong (Wang et al. 2007; Misra et al. 2014; Duran-Quesada et al. 2017; 340 Corrales-Suastegui et al. 2020). It may be noted that we use land based CPC rainfall for this 341 comparison because the time period of this rainfall dataset overlaps with that of CFSR and RSM-

342 ROMS simulation. The RSM-ROMS simulation in Fig. 8c is able to show similar seasonal mean 343 rainfall anomalies as the observations over Guatemala, southern Mexico, Nicaragua, Honduras, 344 and Costa Rica (Fig. 8b). However, the positive rainfall anomalies in RSM-ROMS over Panama 345 and northeast Colombia in Fig. 8c are unsubstantiated in the observations (Fig. 8b).

\section{e) The Mid-Summer Drought}

The iconic feature of the region is the mid-summer drought. This was diagnosed both in

349 the observations and in RSM-ROMS when a relative minimum of rainfall in July and August, was

350 observed between biannual peaks in June and September (Magana et al. 1999). We defined

351 intensity of the mid-summer drought as the difference between the average of the biannual peak

352 and the average of the minimum in the intervening two months (Figs. 9a and b). Their frequency

353 of occurrence is identified in Figs. 9c and d as fraction of seasons with mid-summer drought in the

35425 years $(1986-2010)$.

355 The observations show that the Yucatan region and the Pacific side of the northern part of

356 the CAI (e.g., western coasts of Guatemala, Nicaragua, and San Salvador) exhibit largest intensity

357 (Fig. 9a) and highest frequency (Fig. 9c) of the mid-summer drought. South of Nicaragua, the 
358 frequency of the mid-summer drought drops significantly (Fig. 9c) while the intensity over Costa

359 Rica and Panama are moderate (Fig. 9a). The western coast of Colombia displays high frequency

360 (Fig. 9c), but the intensity is low (Fig. 9a). The RSM-ROMS simulation shows some of these

361 features, like high intensity in the Yucatan Peninsula, Costa Rica, and Panama (Fig. 9b).

362 Furthermore, the meridional gradient in the frequency of the mid-summer drought between north

363 and south of the Nicaraguan western coast in Fig. 9d is also apparent like the observations (Fig.

364 9c). However, RSM-ROMS clearly underestimates the frequency of the drought across CAI. The

365 spatial pattern of the intensity of the drought in RSM-ROMS is reasonable relative to the

366 observations, but the magnitude shows systematic bias like the underestimation over Yucatan

367 Peninsula, Honduras, Guatemala and overestimation over Costa Rica and Panama.

\section{f) Tropical Gyclone activity}

The tropical cyclone activity is shown as track density (which is number of TGs per $1^{\circ} \times 1^{\circ}$

371 grid) in Fig. 10. As noted earlier, Fig. 10 plots the tropical cyclone fix at one day interval over the

372 integration period of 1986-2010. RSM-ROMS (Fig. 10b) shows reasonable distribution of the TGs

373 in comparison to HURDAT2 (Fig. 10a) both over the Caribbean Sea and the eastern Pacific with

374 some notable biases. For example, like HURDAT2, RSM-ROMS shows greater number of TGs

375 in the Caribbean Sea than over the eastern Pacific. Furthermore, RSM-ROMS does not generate

376 TGs below $5^{\circ} \mathrm{N}$ in the eastern Pacific. The distribution of the TGs in the Caribbean Sea with a

377 cluster of high density between the Cayman and Yucatan Basins and over the Nicaraguan Rise in

378 HURDAT2 is comparatively much weaker in RSM-ROMS. In addition, the large density of the

379 TGs in the Bay of Campeche and in the Colombian Basin in RSM-ROMS is unsupported by 
HURDAT2. Likewise, the density of TCs in the eastern Pacific between $10^{\circ}$ to $15^{\circ} \mathrm{N}$ in RSM-

ROMS is less than in HURDAT2.

\section{g) Comparison with $\mathbf{R} 2$}

in the 25 years (1986-2010) The key benefit of dynamic downscaling is its ability to resolve or permit the fine scale features of the regional climate because of the superior horizontal resolution of the regional model. This feature of downscaling in our study has thus far been fairly demonstrated in the fidelity of RSM-ROMS in depicting some mesoscale features like the Costa Rica Dome, the Panama-Colombian and the Papagayo-Tehuantepec Gyres, the atmospheric LLJs, interannual and sub-seasonal variations of rainfall over Central America and the TC activity in the region. The other value of dynamic downscaling is its potential to improve upon the largescale forcing used to force the regional model. Therefore, in our case it would be incumbent to compare the systematic errors of $\mathrm{R} 2$ reanalysis with those from RSM-ROMS. It may however be added, that RSM-ROMS by way of its coupled ocean-atmosphere framework already adds value

394 to downscaling in contrast to either R2 or SODA reanalysis, which are exclusively global 395 atmospheric or oceanic reanalysis, respectively.

397 comparison to RSM-ROMS (Figs. 2i-l), the systematic errors of R2 (Figs. 1la-d) are higher over 398 the whole domain in spring and summer (Table 2). In contrast, R2 rainfall is superior in terms of 399 the mean error in winter (Table 2). An interesting point, however, is that the sign of the systematic 400 errors of rainfall in the tropical eastern Pacific Ocean is nearly opposite between RSM-ROMS and 401 R2 except in the winter season. This may be a result of the air-sea coupling in RSM-ROMS being 402 more active in tropical eastern Pacific Ocean that allows for more degrees of freedom, with the 403 ocean co-evolving with the atmosphere. On the other hand, the systematic errors display largely a 
wet bias over the Caribbean Sea in both R2 and RSM-ROMS, which could be suggesting that the

405 Caribbean region rainfall in RSM-ROMS is being largely dictated by the large-scale atmospheric 406 conditions of R2.

407 Similarly, the comparison of the systematic errors of precipitable water between R2 (Figs.

408 11e-h) and RSM-ROMS (Figs. 3i-l) indicate that the latter is an improvement over R2 in the boreal

409 winter and spring seasons across the domain (Table 3). However, in the boreal summer and fall,

410 the systematic errors of precipitable water are nearly identical in R2 and RSM-ROMS. It is

411 apparent from this comparison that the systematic errors in precipitable water are far more

412 consistent in RSM-ROMS in relation to R2, which is in contrast to the systematic errors of rainfall.

413 This is because specific humidity is one of the prescribed variables at the lateral boundaries of

414 RSM-ROMS and hence the evolution of humidity is constrained to that imposed at the lateral

415 boundaries. However, rainfall is not constrained by the lateral boundaries of RSM-ROMS.

416 The comparison of the low-level winds at 925hPa in Fig. 7 reveals that despite the coarse

417 resolution of $\mathrm{R} 2$, the LLJs are reasonably depicted including their seasonal cycle. The RSM-

418 ROMS in most instance replicates this seasonal cycle of the LLJs in R2 except in the case of PaLLJ

419 (Fig. 7g), where the jet in RSM-ROMS is systematically stronger and shows far more variability

420 than R2. We believe this is one aspect of the RSM-ROMS simulation that could be further

421 improved with a more realistic prescription of the orography than used in this study (Fig. 1).

422 One of the important forcing to the ocean is the surface wind stress, which is demonstrably

423 significant for the mesoscale variations of the surface ocean currents in the region (Fiedler 2002;

424 Sheng and Tang 2003). The easterly wind stress in the Caribbean Sea and in the northeastern

425 Pacific Ocean are dominant both in the reanalysis and in RSM-ROMS (Fig. 12). Similarly,

426 southerly and northeasterly wind stress over the equatorial eastern Pacific Ocean and over the

427 Colombian Basin, respectively is also apparent in Fig. 12. Similarly, the wind stress curl shows 
428 regions of strong upwelling and downwelling in both oceans that have distinct seasonality

429 associated with the Costa Rica Dome, ITCZ in the eastern Pacific and the LLJs (Fig. 12). There

430 are however subtle differences between R2 (Figs. 12e-h) and RSM-ROMS (Figs. 12i-l). For

431 example, the upwelling associated with Costa Rica Dome and Panama-Colombia Gyre is stronger

432 in RSM-ROMS (and closer to CFSR in Figs. 12a-d) compared to R2 (Figs. 12e-h). However, the

433 downwelling over the eastern equatorial Pacific Ocean is stronger in RSM-ROMS compared to

434 R2 or CFSR (Fig. 12).

435

\section{Conclusions}

In this study we have examined the fidelity of an unprecedented multi-decadal regional coupled ocean-atmosphere model (RSM-ROMS) simulation over Central America at 15km grid spacing. The last such regional coupled ocean-model atmosphere modeling study over the region

440 was conducted by Xie et al. (2007), which was conducted at $0.5^{\circ}$ grid spacing over a 7 -year period.

441 The CAI, by its geography has a very rich amalgam of variations that feature both the surrounding

442 oceans and over the land surface, which warrants the use of such relatively high resolution coupled 443 ocean-atmosphere models. The current state-of-the-art global climate models at a nominal spatial 444 resolution ranging between $2^{\circ}$ to $1^{\circ}$ are highly inadequate for either simulating or projecting future 445 climate over the region.

446 The highlights of the RSM-ROMS simulation over the CAI region, forced with R2 global 447 atmospheric reanalysis and SODA ocean reanalysis at the lateral boundaries are as follows:

448 - The seasonal cycle of precipitation over CAI and the surrounding oceans is reasonable. It 449 had the least error in the spring followed by summer with the wet bias in the winter and 450 the dry bias in the fall being significantly larger. Interestingly, seasonal precipitation bias 
over the eastern Pacific Ocean in R2 is opposite to those in the RSM-ROMS simulation suggesting the potential role of air-sea coupling in the basin.

453 - The seasonal cycle of precipitable water clearly shows the meridional gradient of high precipitable water over the equatorial latitudes to lower precipitable water in the subtropics from winter through fall in both observations and RSM-ROMS simulation. However, the systematic errors in simulated precipitable water by RSM-ROMS is very similar to those in R2, suggesting the strong influence of the lateral boundary conditions on the simulation.

- The seasonal cycle of the upper ocean in RSM-ROMS shows the gradual cooling and latitudinal expansion of the equatorial Pacific cold tongue like the observations. Furthermore, the warming of the northeastern Pacific Ocean and the Caribbean Sea from winter through fall is also well captured in the RSM-ROMS simulation. However, warm SST bias of RSM-ROMS in the oceans that contrasts with the Costa Rica Dome (measured by the depth of the $20^{\circ} \mathrm{C}$ isotherm) being perennially shallower than the SODA reanalysis is apparent. simulation follow those in R2 and is reasonably similar to CFSR. However, RSM-ROMS like the R2 underestimates these LLJs with respect to CFSR, except for PaLLJ where it is comparable to CFSR. We strongly believe that this feature could be further improved in RSM-ROMS by improving the representation of the topography. By adopting a more realistic topography in the RSM, these LLJs or gap winds could become stronger and may also affect the momentum flux in the oceans and thereby also increase the mixing in the oceans that currently seems to be weaker in RSM-ROMS. 
473

474

475

476

477

478

479

480

481

482

483

484

485

486

487

488

489

490

491

492

493

494

495

- The interannual variations of the CLLJ in the summertime show verifiable precipitation response over the CAI in the RSM-ROMS simulation, especially over Honduras Nicaragua, and Costa Rica.

- The iconic feature of the mid-summer drought in the CAI in RSM-ROMS shows some similarities with observations. For example, the observed relative maximum of intensity over the Yucatan Peninsula, Guatemala, San Salvador, Costa Rica and Panama with a minimum over Honduras is well picked. Similarly, the observed meridional gradient of lower and higher frequency to the south and to the north of Nicaragua is also reasonably simulated in RSM-ROMS.

- The track density of the TGs in RSM-ROMS shows some important observed features like there is a greater distribution of TCs in the Caribbean Sea than over the eastern Pacific and there are no TCs generated south of $5^{\circ} \mathrm{N}$ in the eastern Pacific.

Despite these highlights, there is significant room for improving the RSM-ROMS simulation. The systematic errors of wet bias in the winter and dry bias in other seasons, underestimation of the magnitude of the LLJs, the seasonal shift the annual cycle of the Costa Rica Dome, underestimation of the frequency of the mid-summer drought, and the higher density of TGs in the Bay of Campeche and Colombian Basin are most apparent.

\section{Declarations}

Author Contributions: Corresponding author contributed to the study conception and design. Material preparation, data collection and analysis were equally done by V. Misra and C. B. Jayasankar. All authors have read and approved the final manuscript.

Funding: No funds, grants, or other support was received for conducting this study. 
496 Conflicts of interest/competing interests: None.

497 Availability of data and material: The authors are willing to share the data from the model upon request.

499 Ethics approval: COPE guidelines have been followed.

500 Consent to participate: Not applicable. 


\section{References}

503 Afonso, O. C., 2011: Natural disasters and migration: Storms in Central America and the Caribbean and immigration to the U.S. UG Davis Undergrad. Res. J., 14, 1-18, http:/ / explorations.ucdavis.edu/docs/2011/andrade.pdf.

Alpert, J., M. Kanamitsu, P. Caplan,J. Sela, and G. White, 1988: Mountain induced gravity wave drag parameterization in the NMC medium-range forecast model. In Conference on Numerical Weather Prediction, 8th , Baltimore, MD. 726-733.

Amador, J. A., A. M. Durán-Quesada, E. R. Rivera, G. Mora, F. Sáenz, B. Calderón, and N. Mora, 2016: The easternmost tropical Pacific. Part II: Seasonal and intraseasonal modes of atmospheric variability. Revista de Biología Tropical, 64(1), S23-S57.

512 Amador, J. A., and V. O. Magaña, 1999: Dynamics of the low level jet over the Caribbean, in 23rd Conference on Hurricanes and Tropical Meteorology, pp. 868-869, Am. Meteorol.

Andrade, C. A., and E. D. Barton, 2000: Eddy development and motion in the Caribbean Sea. J. Soc., Dallas, Texas.

\section{7} Geophys. Res., 105, 26 191-26 201.

521 Carton, J. A., and B. S. Giese, 2008: A reanalysis of ocean climate using Simple Ocean Data

524 Chen, M., Shi, W., Xie, P., Silva, V.B.S., Kousky, V.E., Wayne Higgins, R., Janowiak, J.E., 2008. 
precipitation.

J. Geophys.

Res.

113

D04110. https://doi.org/10.1029/2007JD009132.

528 Chou, M. D., K. T. Lee, S. C.Tsay, and Q. Fu, 1999: Parameterization for cloud longwave 529 scattering for use in atmospheric models. Journal of climate. 12(1):159-169.

530

Chou, M. D. and K. T. Lee, 1996: Parameterizations for the absorption of solar radiation by water vapor and ozone. J Atmos Sci 53:1203-1208.

533

Corrales-Suastegui, A., R. Fuentos-Franco, and E. G. Pavia, 2020: The mid-summer drought over Mexico and Central America in the 21 ${ }^{\text {st }}$ century. Int. J. Climatol., doi:10.1022/joc.6296.

Danielson, J. J. and D. B. Gesch, 2011: Global multi-resolution terrain elevation data, doi:10.5066/F7DF6PQS.

Davis, R. E., B. P. Hayden, D. A. Gay, W. L. Phillips, and G. V. Jones, 1996: The North Atlantic Subtropical Anticyclone. J. Clim., 10, 728-744.

Durán-Quesada, A. M., L. Gimeno, L., and J. Amador, 2017: Role of moisture transport for Central American precipitation. Earth System Dynamics, 8, 147-161.

Enfield, D.B. and Alfaro, E.J. (1999) The dependence of Caribbean rainfall on the interaction of the tropical Atlantic and Pacific Oceans. Journal of Climate, 12, 2093-2103. https://doi.org/10.1175/1520-0442(1999)012<2093:TDOCRO>2.0.CO;2.

Ek, M. B., K. E. Mitchell, Y. Lin, E. Rogers, P. Grunmann, V. Koren, G. Gayno, J. D. Tarpley, 2003: Implementation of Noah land surface model advances in the National Centers for Environmental Prediction operational mesoscale Eta model. Journal of Geophysical

547 Ezer, T., H. Arango, and A. F. Shchepetkin, 2002: Developments in terrain-following ocean models: intercomparisons of numerical aspects. Ocean Modelling, 4, 249-267. 
549 Fiedler, P. C., 2002: The annual cycle and biological effects of the Costa Rica Dome, Deep-Sea $550 \quad$ Research I, 49, 321-338.

551 Fratantoni, D. F., 2001: North Atlantic surface circulation during the 1990's observed with satellite-tracked drifters. J. Geophys. Res., 106, 22 067-22 093.

553 Fuentes-Franco, R., Coppola, E., Giorgi, F., Pavia, E.G., Diro, G.T. and Graef, F. (2015) Interannual variability of precipitation over southern Mexico and Central America and its relationship to sea surface temperature from a set of future projections from CMIP5 GCMs and RegCM4 CORDEX simulations. Climate Dynamics, 45, 425-440. https://doi.org/10.1007/s00382-014-2258-6.

Gimeno, L., A. Stohl, R. M.Trigo, F. Dominguez, K. Yoshimura, K., L. Yu, and coauthors, 2012: Oceanic and terrestrial sources of continental precipitation. Reviews of Geophysics, 50(4), RG4003.

Haidvogel, D. B., H. G. Arango, K. Hedstrom, A. Beckmann, P. Malanotte-Rizzoli, A. F. Shchepetkin, 2000: Model evaluation experiments in the North Atlantic Basin: simulations in nonlinear terrain-following coordinates. Dynamics of atmospheres and oceans. $32(3): 239-81$.

Ham, S., K. Yoshimura, and H. Li, 2016: Historical dynamical downscaling for East Asia with the Atmosphere and Ocean Coupled Regional Model. J. Meteor. Soc. Japan, 94A, 199-208, https://doi.org/10.2151/jmsj.2015-046.

Heather, H. M. and M. A. Bourassa, 2014: The effects of gap-wind-induced vorticity, the monsoon trough, and the ITCZ on East Pacific Tropical cyclogenesis. Mon. Wea. Rev., 142, 13121325.

Hidalgo, H. G., A. M. Durán-Quesada, J. A. Amador, and E. J. Alfaro, 2015: The Caribbean Low-Level Jet, the Inter-Tropical Convergence Zone and Precipitation Patterns in the 

Geography, 97(1), 41-59.

575 Hong, S. Y. and H. L. Pan, 1996: Nonlocal boundary layer vertical diffusion in a medium-range

576 forecast model. Monthly weather review, 124(10):2322-2339.

577 Juang, H. M. and M. Kanamitsu, 1994: The NMC nested regional spectral model, Mon. Weather $578 \quad$ Rev., 122:3-26.

579 Kanamitsu, M., K. Yoshimura, B. Y. Yhang, S. Y. Hong, 2010: Errors of interannual variability 580 and trend in dynamical downscaling of reanalysis. Journal of Geophysical Research: $581 \quad$ Atmospheres. 115(D17).

582 Kanamitsu, M., W. Ebisuzaki, J. Woollen, S. K. Yang, J. J. Hnilo, M. Fiorino, and G. L. Potter, 583 584 2002: NCEP-DOE AMIP-II Reanalysis (R-2). Bull. Amer. Meteor. Soc., 83, 1631-1643, https://doi.org/10.1175/BAMS-83-11-1631.

585 Kanamaru, H. and M. Kanamitsu, 2007: Scale-selective bias correction in a downscaling of global 586 reanalysis using a regional model. Mon Weather Rev 135:334-350.

587 Kessler, W. S., 2006: The circulation of the eastern tropical Pacific. A review. Prog. Oceanogr., 588 69, 181-217.

589 King, F.D., 1986. The dependence of primary production in the mixed layer of the eastern tropical 590 Pacific on the vertical transport of nitrate. Deep-Sea Research I 33, 733-754.

591 Landsea, C. W. and J. L. Franklin, 2013: Atlantic Hurricane Database Uncertainty and 592 Presentation of a New Database Format. Mon. Wea. Rev., 141, 3576-3592.

593 Large, W. G., and J. G. McWilliams, and S. G. Doney, 1994: Oceanic vertical mixing: A review 594 and a model with a nonlocal boundary layer parameterization. Reviews of Geophysics, 595 32(4):363-403. 
Li, H., and V. Misra, 2014: Thirty-two-year ocean-atmosphere coupled downscaling of global reanalysis over the IntraAmerican Seas. Climate Dyn., 43, 2471-2489, https://doi.org/ 10.1007/s00382-014-2069-9.

Li, H., M. Kanamitsu, S. -Y. Hong, K. Yoshimura, D. R. Cayan, and V. Misra, 2014: A highresolution ocean-atmosphere coupled downscaling of the present climate over California. Clim. Dyn., 42(3-4), 701-714, doi:10.1007/s00382-013-1670-7.

Magaña, V., J. A. Amador, and S. Medina, 1999: The midsummer drought over Mexico and Central America. Fournal of Climate, 12(6), 1577-1588.

604 Maldonado, T., E. J. Alfaro, and H. G. Hidalgo, 2018: A review of the main drivers and variability of Central America's Climate and seasonal forecast systems. Rev. Biol. Trop., 66, S153175.

Mapes, B. E., P. Liu, and N. Buenning, 2005: Indian monsoon onset and the Americas midsummer drought: Out-of equilibrium responses to smooth seasonal forcing. J. Climate, 18, 1109

Misra, V., H. Li, and M. Kozar, 2014: The precursors in the Intra-Americas Seas to seasonal climate variations over North America. J. Geophys. Res. (Oceans), 119 (5), 2938-2948,

613 Misra, V., A. Mishra, and A. Bhardwaj, 2018: Simulation of the intraseasonal variations of the 614 Indian summer monsoon in a regional coupled ocean-atmosphere model. J. Climate, 31, 615 3167-3185.

616 Moorthi, S. and M. J. Suarez, 1992: Relaxed Arakawa-Schubert. A parameterization of moist 617 convection for general circulation models. Monthly Weather Review, 120(6):978-1002. 
618 Morris, S. S., O. N. -Gonzales, C. Carletto, M. Munguia, J. M. Medina, and Q. Wodon, 2002:

619 Hurricane Mitch and the Livelihoods of the Rural Poor in Honduras. World Development, $620 \quad 30,49-60$.

621 Munoz, E., A. J. Busalacchi, S. Nigam, and A. Ruiz-Barradas, 2008: Winter and summer structure 622 of the Caribbean low-level jet. J. Climate, 1260-1276,

623 https://doi.org/10.1175/2007JCLI1855.1.

624 NOAA National Geophysical Data Genter, 2006: 2-minute Gridded Global Relief Data 625 (ETOPO2)v2. NOAA National Centers for Environmental Information. 626 https://doi.org/10.7289/V5J1012Q.

627 Perez,J. S., H. H. Cervantes, and G. Gutierrez, 2000: Gyres observed with altimetry in the tropical 628 Pacific Ocean. SPIE proceedings, vol. 4172, Remote Sensing of the Ocean and the Sea $629 \quad$ Ice, https://doi.org/10.1117/12.411707.

630 Poveda, G., and O.J. Mesa, 1999: The westerly Colombian low-level jet (“CHOCO”) and two 631 other low-level jets over Colombia: Climatology and variability during ENSO phases (In 632 633 Spanish), Revista Academia Colombiana de Ciencias, Exactas, Físicas y Naturales, Vol.

634 Quirós-Badilla, E., \& Hidalgo-León, H. G. (2016). Variabilidad y conexiones climáticas de la zona 635 de convergencia intertropical del Pacífico este. Topicos Meteorologicos y Oceanograficos, 15(1), $636 \quad 21-36$.

637 Retana, J. A., 2012: Eventos hidrometeorológicos extremos lluviosos en Costa Rica desde la 638 perspectiva de la adaptación al cambio en el clima. Ambientales, 44, 5-16.

639 Saha, S. and coauthors, 2010: The NCEP climate forecast system reanalysis. Bull Am Soc., 91, 640 1015-1058, doi:10.1175/2010BAMS3001.1. 
641 Schultz, D. M., Bracken, W. E., \& Bosart, L. F. (1998). Planetary- and Synoptic-Scale Signatures

642 Associated with Central American Cold Surges. Monthly Weather Review, 126(1), 5-27.

643 Shchepetkin, A. F. and J. C. McWilliams, 2005: The regional oceanic modeling system (ROMS):

644 a split-explicit, free-surface, topography-following-coordinate oceanic model. Ocean $645 \quad$ Modelling. 9(4):347-404.

646 Spencer, N. and M. -A. Urquhart, 2018: Hurricane strikes and migration: evidence from storms 647 in Central America and the Caribbean. Weather, Climate, and Society, 10, 569-577.

648 Sheng, J. and L. Tang, 2003: A numerical study of circulation in the Western Caribbean Sea. J. 649 Phys. Oceanography, 33, 2049-2069.

650 Tatsumi, Y., 1986: A spectral limited area model with time dependent lateral boundary conditions 651

652 and its application to a multi-level primitive equation model.J. Meteor. Soc. Japan, 64:637663.

653 Tiedtke, M., 1983: The sensitivity of the time-mean large-scale flow to cumulus convection in the EGMWF model. In: Proceedings of ECMWF Workshop on Convective in Large-scale Models. European Centre for Medium-Range Weather Forecasts, Reading, United

657 Timmermann, A. and Coauthors, 2007: The influence of a weakening of the Atlantic meridional overturning circulation on ENSO.J. Climate, 20, 4899-4919.

659 Ullrich, P. A. and C. M. Zarzycki, 2017: TempestExtremes v1.0: A framework for scale-insensitive 660 pointwise feature tracking on unstructured grids. Geosci. Model Dev. Discuss., doi:10.5194/gmd-2016-217.

662 Umlauf, L. and H. Burchard, 2003: A generic length-scale equation for geophysical turbulence 663 models. Journal of Marine Research. 61(2):235-65. 
664 Wang, C., and D. B. Enfield, 2001: The tropical western hemisphere warm pool. Geophys. Res. $665 \quad$ Lett., 28, 1635-1638.

666 Wang, C., 2007: Variability of the Caribbean low-level jet and its relations to climate. Clim. Dyn., $667 \quad 29: 411-422$.

668 Wang, C., S. -K. Lee, and D. B. Enfield, 2007: Impact of the Atlantic Warm Pool on the Summer 669 Climate of the Western Hemisphere. Fournal of Climate, 20(20), 5021-5040.

670 Wang, C., S. -K. Lee, and D. B. Enfield, 2008: Climate response to anomalously large and small 671 Atlantic Warm pools during the summer. J. Climate, 21, 2437-2450.

672 Webster, S., A. R. Brown, D. R. Cameron, and C. P. Jones, 2003: Improvements to the 673 representation of orography in the Met Office Unified Model. Quart. Roy. Soc., 129, 19896742010.

675 Wyrtki, K., 1964: Upwelling in the Costa Rica Dome. Fishery Bulletin 63, 355-372.

676 Xie, P., Yatagai, A., Chen, M., Hayasaka, T., Fukushima, Y., Liu, C., Yang, S., 2007. A gauge 677 based analysis of daily precipitation over East Asia. J. Hydrometeorol. 8, 607-626.

678 https://doi.org/10.1175/JHM583.1.

679 Xie, S. -P., Y. Okumura, T. Miyama, A. Timmermann, 2008: Influences of Atlantic climate 680 change on the tropical Pacific via the Central America Isthmus. J. Climate, 21, 681 3914-3928.

682 Zhao, Q. and F. H. Carr, 1997: A prognostic cloud scheme for operational NWP models. Monthly 683 Weather Review. 125(8):1931-1953.

684

685 
Table 1: Outline of the physical parameterization schemes used in RSM

\begin{tabular}{|c|c|}
\hline $\begin{array}{c}\text { Atmospheric Model (Regional } \\
\text { Spectral Model) }\end{array}$ & Reference \\
\hline Gravity wave drag & Alpert et al. (1988) \\
\hline Boundary layer & Hong and Pan (1996) \\
\hline Clouds & Zhao and Carr (1997) \\
\hline Deep convection & Moorthi and Suarez (1992) \\
\hline Land surface Model & Ek et al. (2003) \\
\hline Longwave radiation & Chou et al. (1996) \\
\hline Shortwave radiation & Chou and Suarez (1994) \\
\hline Shallow convection & Tiedtke (1983) \\
\hline
\end{tabular}


Table 2: Mean error of seasonal mean precipitation in R2 and RSM-ROMS (units: $\mathrm{mm} /$ day)

\begin{tabular}{|l|l|l|l|l|l|l|l|l|}
\hline \hline & \multicolumn{2}{|c|}{ DJF } & \multicolumn{2}{c|}{ MAM } & \multicolumn{3}{c|}{ JJA } & \multicolumn{2}{c|}{ SON } \\
\cline { 2 - 8 } & R2 & $\begin{array}{c}\text { RSM- } \\
\text { ROMS }\end{array}$ & R2 & $\begin{array}{c}\text { RSM- } \\
\text { ROMS }\end{array}$ & R2 & $\begin{array}{c}\text { RSM- } \\
\text { ROMS }\end{array}$ & R2 & $\begin{array}{c}\text { RSM- } \\
\text { ROMS }\end{array}$ \\
\hline $\begin{array}{l}\text { Tropical Eastern Pacific } \\
\text { (only ocean points within } \\
95^{\circ} \mathrm{W} \text { to } 78^{\circ} \mathrm{W} \text { and } 00^{\circ} \text { to } \\
14^{\circ} \mathrm{N} \text {, west of the } \\
\text { isthmus) }\end{array}$ & 4.53 & 4.48 & 3.27 & -1.51 & 5.86 & -4.25 & 5.28 & -5.12 \\
\hline $\begin{array}{l}\text { Central America isthmus } \\
\text { (only land points within } \\
95^{\circ} \mathrm{W} \text { to } 78^{\circ} \mathrm{W} \text { and } 6^{\circ} \mathrm{N} \\
\text { to } 21^{\circ} \mathrm{N} \text { ) }\end{array}$ & 0.03 & 6.19 & 0.54 & -0.11 & 2.68 & -1.81 & 0.95 & -4.29 \\
\hline $\begin{array}{l}\text { Caribbean Sea (only } \\
\text { ocean points within } \\
95^{\circ} \mathrm{W} \text { to } 75^{\circ} \mathrm{Wand} 9^{\circ} \mathrm{N} \\
\text { to } 22^{\circ} \mathrm{N} \text {, east of the } \\
\text { isthmus) }\end{array}$ & 0.84 & 7.93 & 0.75 & 1.82 & 6.07 & 3.39 & 4.06 & -0.87 \\
\hline
\end{tabular}

691 
Table 3: Mean error of seasonal mean precipitable water in $R 2$ and RSM-ROMS

693 (units: $\mathbf{K g} / \mathbf{m}^{2}$ )

\begin{tabular}{|l|l|l|l|l|l|l|l|l|}
\hline \hline & \multicolumn{2}{|c|}{ DJF } & \multicolumn{2}{c|}{ MAM } & \multicolumn{3}{c|}{ JJA } & \multicolumn{2}{c|}{ SON } \\
\cline { 2 - 8 } & R2 & $\begin{array}{c}\text { RSM- } \\
\text { ROMS }\end{array}$ & R2 & $\begin{array}{c}\text { RSM- } \\
\text { ROMS }\end{array}$ & R2 & $\begin{array}{c}\text { RSM- } \\
\text { ROMS }\end{array}$ & R2 & $\begin{array}{c}\text { RSM- } \\
\text { ROMS }\end{array}$ \\
\hline $\begin{array}{l}\text { Tropical Eastern Pacific } \\
\text { (only ocean points within } \\
95^{\circ} \mathrm{W} \text { to } 78^{\circ} \mathrm{W} \text { and } 0^{\circ} \text { to } \\
\begin{array}{l}14^{\circ} \mathrm{N} \text {, west of the } \\
\text { isthmus }\end{array}\end{array}$ & -2.63 & -1.45 & -2.09 & -1.32 & -7.41 & -7.39 & -7.76 & -7.73 \\
\hline $\begin{array}{l}\text { Central America isthmus } \\
\text { (only land points within } \\
95^{\circ} \mathrm{W} \text { to } 78^{\circ} \mathrm{W} \text { and } 6^{\circ} \mathrm{N} \\
\text { to } 21^{\circ} \mathrm{N} \text { ) }\end{array}$ & 1.97 & 2.07 & 2.15 & 2.31 & -7.43 & -5.97 & -5.72 & -4.5 \\
\hline $\begin{array}{l}\text { Caribbean Sea (only } \\
\text { ocean points within } \\
95^{\circ} \mathrm{W} \text { to } 75^{\circ} \mathrm{Wand} 9^{\circ} \mathrm{N} \\
\text { to } 22^{\circ} \mathrm{N} \text {, east of the } \\
\text { isthmus) }\end{array}$ & 1.82 & 1.71 & 3.27 & 3.26 & -4.49 & -4.28 & -4.79 & -4.67 \\
\hline
\end{tabular}

694 


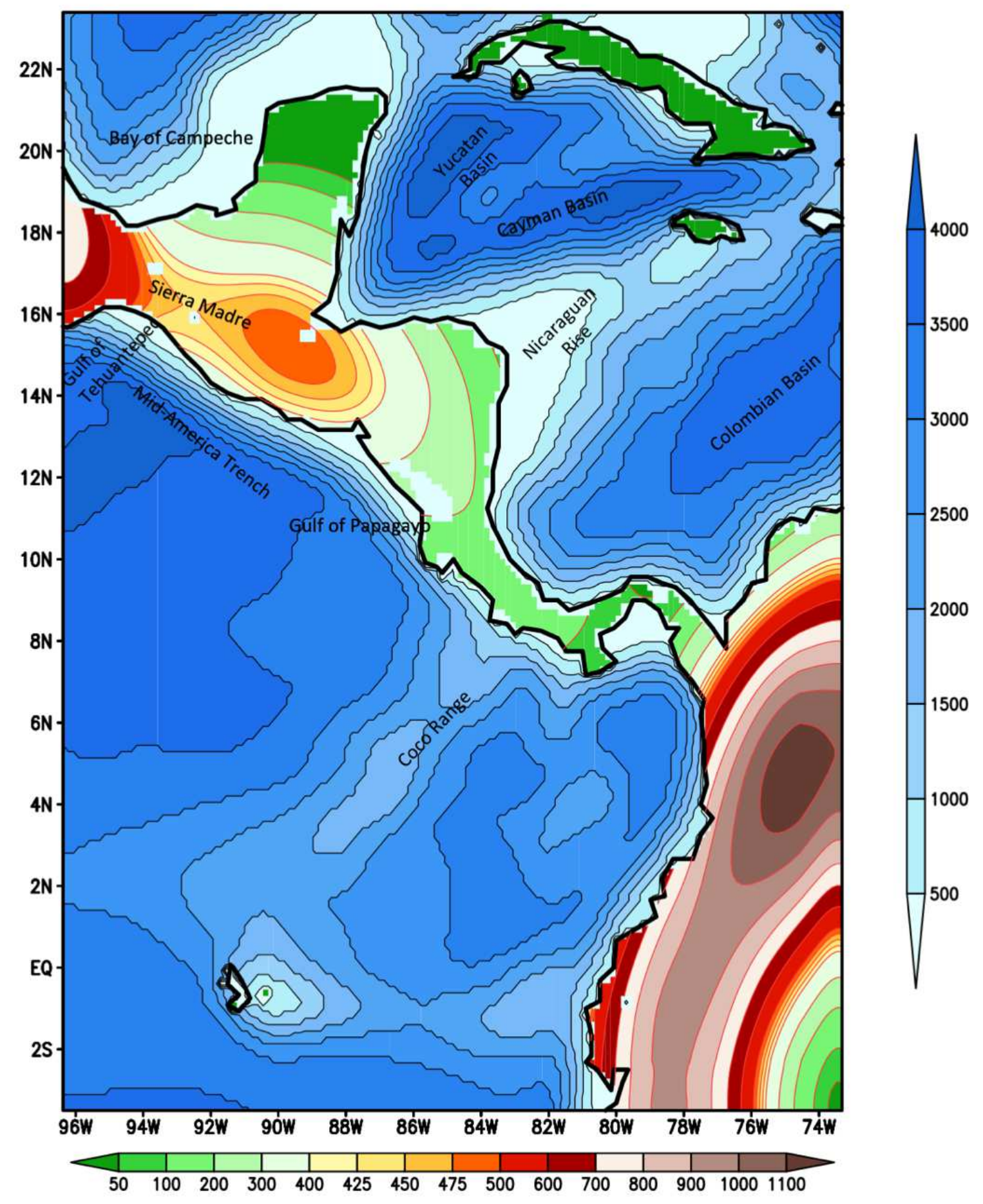

Figure 1: The ocean bathymetry (color bar on the right) and land topography (color bar at the 698 bottom) of the regional domain of RSM-ROMS used in the study. Some bathymetric features and 699 geographical locations referenced in the text are noted in the figure. The units are in meters. 


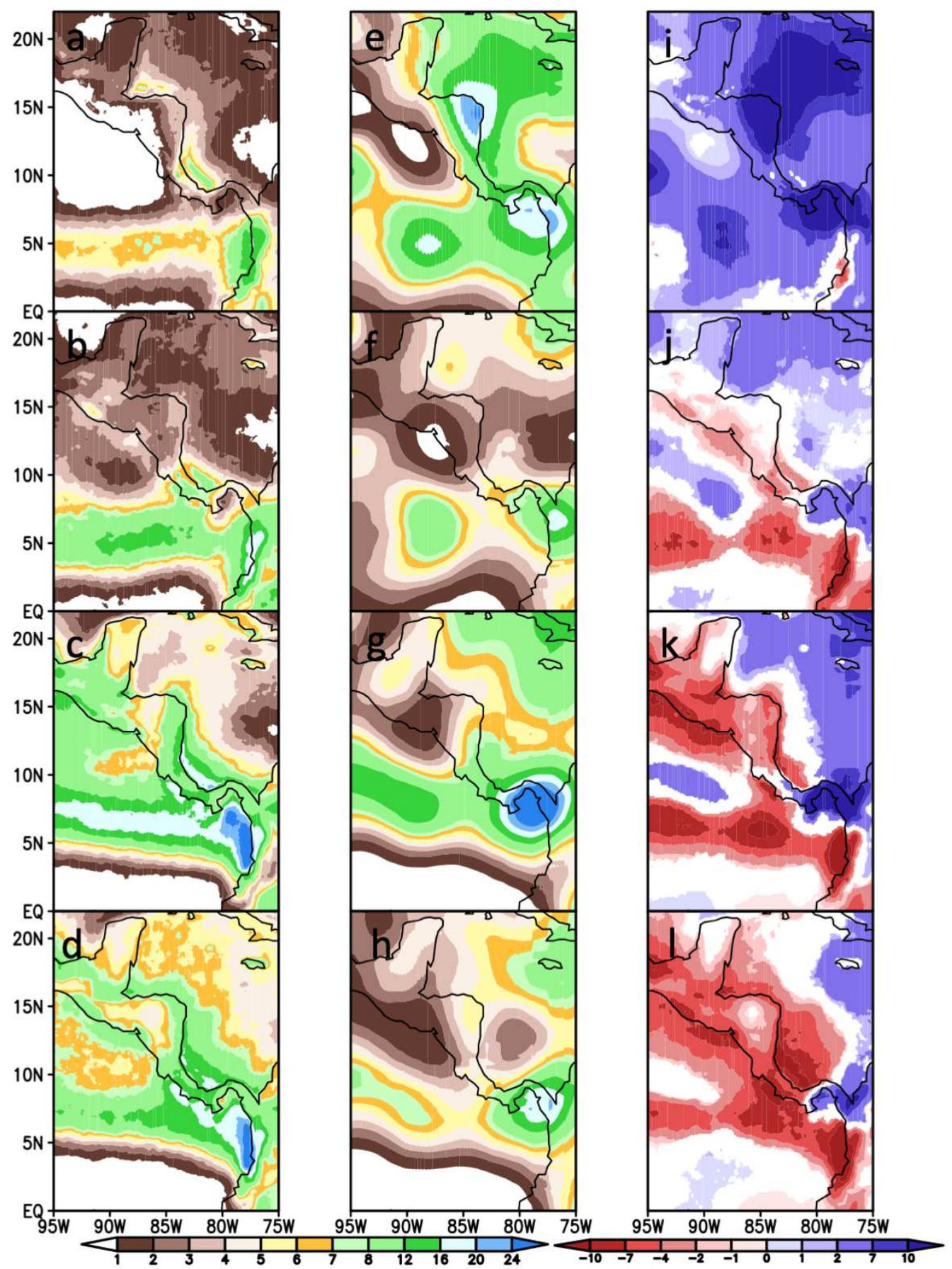

702
Figure 2: The seasonal climatological rainfall (mm day ${ }^{-1}$; shaded) from (a, b, c, d) observations (IMERG) and (e, f, g, h) RSM-ROMS for (a, e) December-January-February, (b, f) March-AprilMay, (c, g) June-July-August, and (d, h) September-October-November seasons. The corresponding seasonal systematic errors (shaded only if they exceed 95\% confidence interval) of RSM-ROMS is shown in (i, j, k, and l). 


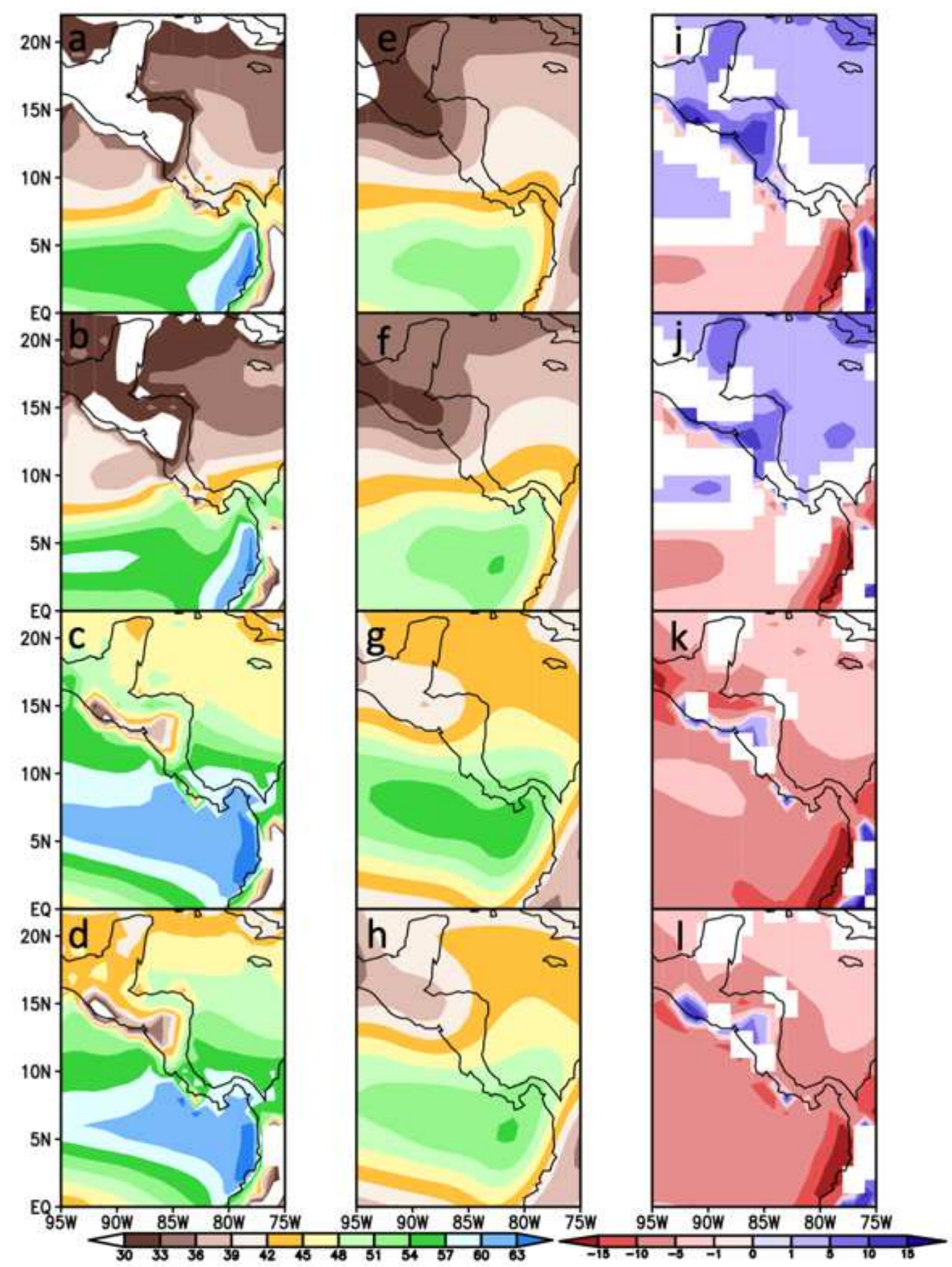

Figure 3: The seasonal climatological precipitable water $\left(\mathrm{Kgm}^{-2}\right.$; shaded), (a, b, c, d) observations 711 (NVAP), and (e, f, g, h) RSM-ROMS for (a, e) December-January-February, (b, f) March-April712 May, (c, g) June-July-August, and (d, h) September-October-November seasons. The 713 corresponding systematic errors (shaded only if they exceed 95\% confidence interval) of RSM714 ROMS is shown in (i,j, $\mathrm{k}$, and $\mathrm{l})$. 


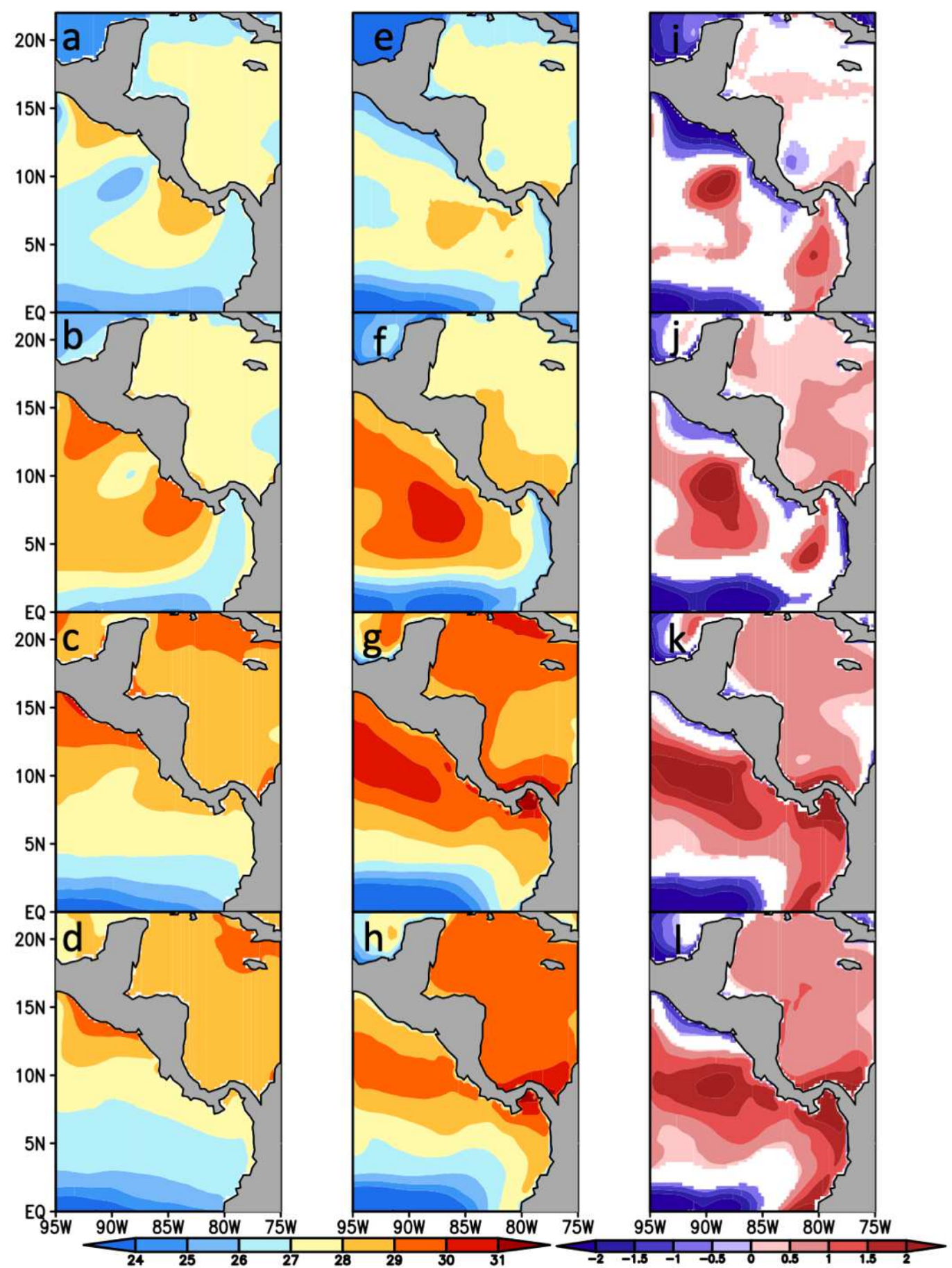

717 Figure 4: The seasonal climatological SST $\left({ }^{\circ} \mathrm{C}\right.$; shaded), (a, b, c, d) observations (NOAA 718 OISSTv2), and (e, f, g, h) RSM-ROMS for (a, e) December-January-February, (b, f) March-April719 May, (c, g) June-July-August, and (d, h) September-October-November seasons. The 720 corresponding systematic errors (shaded only if they exceed 95\% confidence interval) of RSM721 ROMS is shown in (i, j, $\mathrm{k}$, and $\mathrm{l})$. 

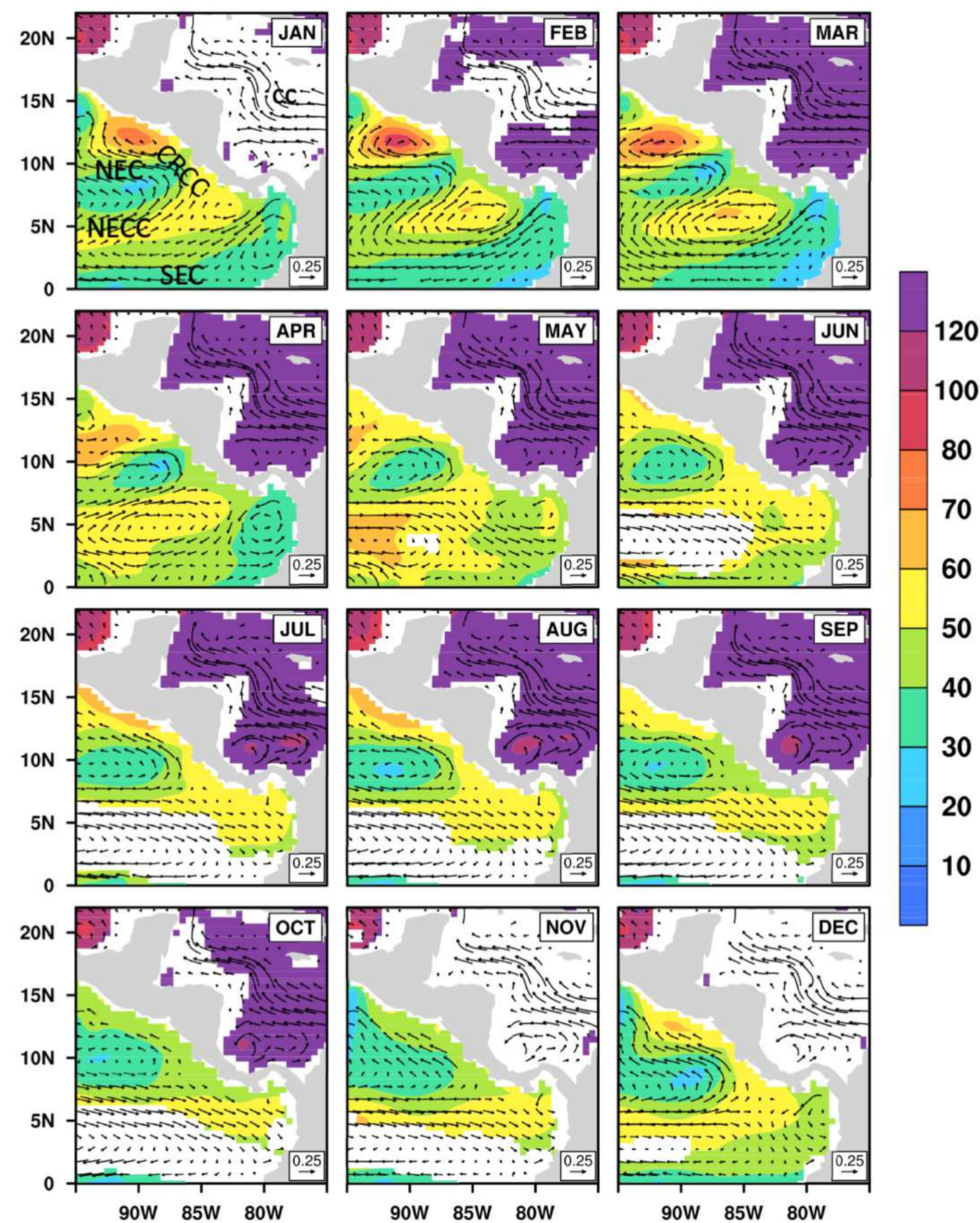

Figure 5: The monthly mean climatology of the thermocline depth (measured as the depth of

724 the $20^{\circ} \mathrm{C}$ isotherm) overlaid with surface ocean currents $\left(\mathrm{ms}^{-1}\right)$ from SODA. The prominent 725 surface ocean currents in the region like the westward flowing North Equatorial Current (NEG) 726 and South Equatorial Current (SEG), eastward flowing North Equatorial Countercurrent

727 (NECG), and northwestward flowing Costa Rica Coastal Current (CRCG) of the Pacific and the 728 Caribbean Current $(\mathrm{CC})$ in the Atlantic are identified in the first panel. 

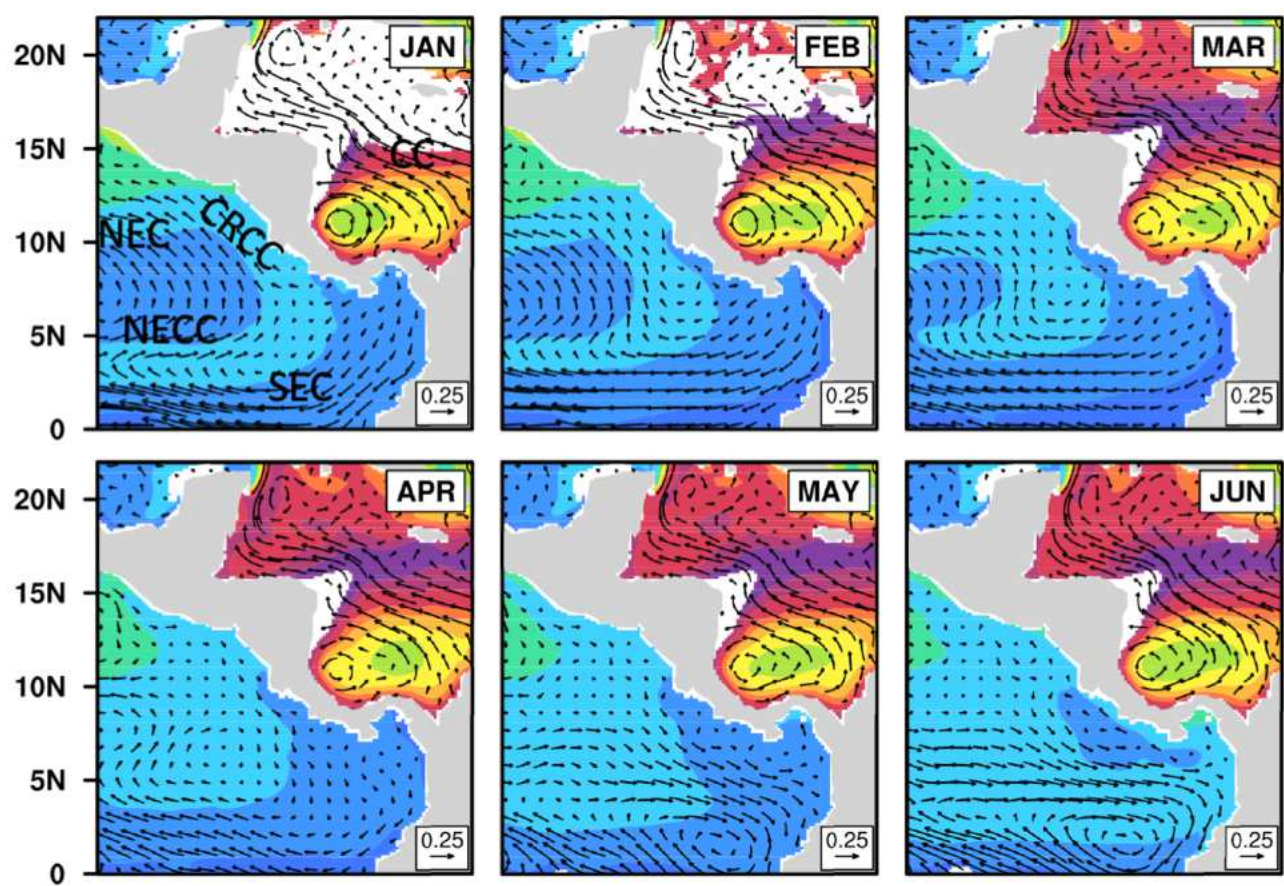

$\square 120$
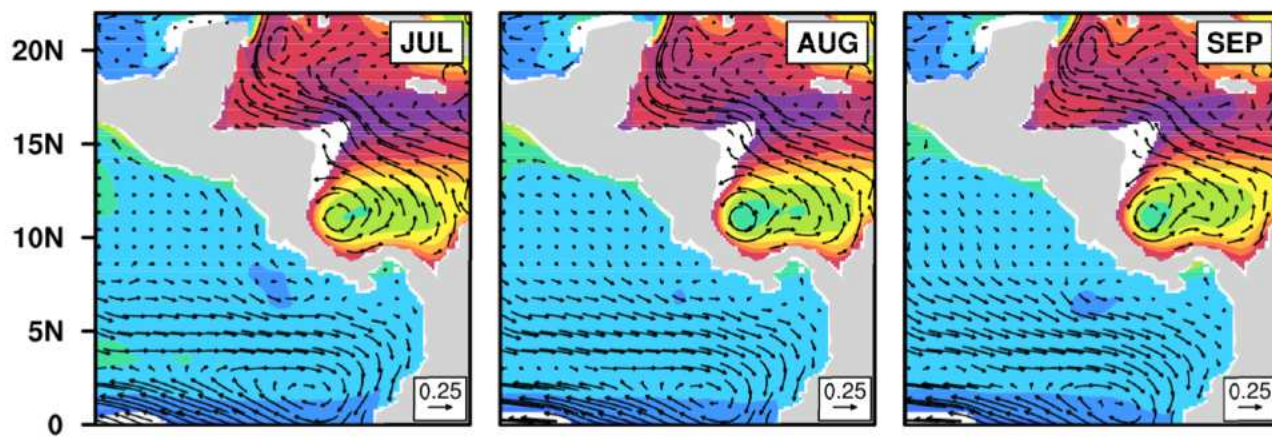

$-100$
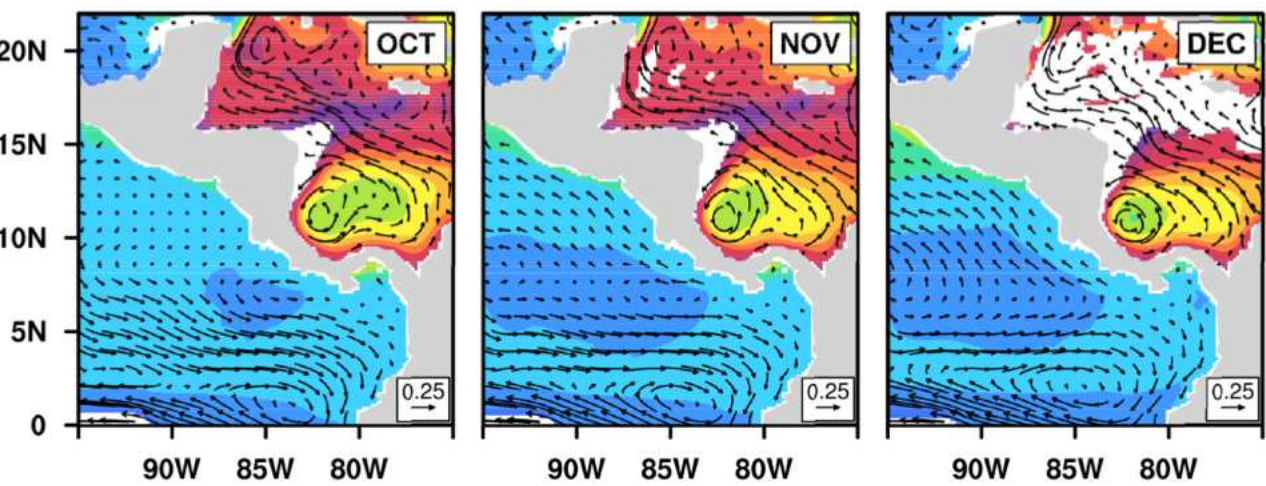

Figure 6: The monthly mean climatology of the thermocline depth (measured as the depth of the $20^{\circ} \mathrm{C}$ isotherm) overlaid with surface ocean currents from the RSM-ROMS simulation. The 733 prominent surface ocean currents $\left(\mathrm{ms}^{-1}\right)$ in the region like the westward flowing North Equatorial 734 Current (NEG) and South Equatorial Current (SEG), eastward flowing North Equatorial 735 Countercurrent (NECG), and northwestward flowing Costa Rica Coastal Current (CRCG) of the 736 Pacific and the Caribbean Current $(\mathrm{CG})$ in the Atlantic are identified in the first panel. 

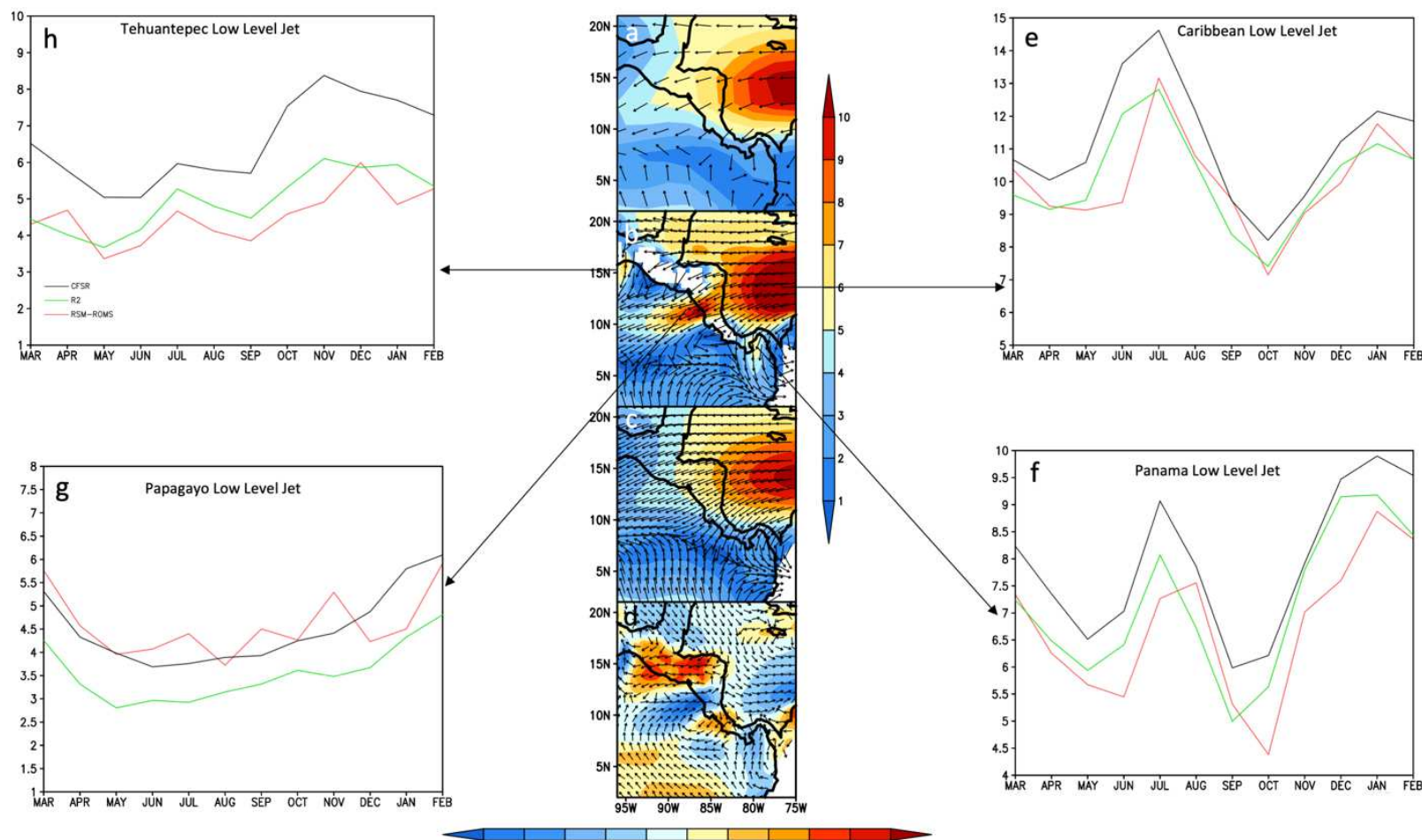

Figure 7: The climatological annual mean 925hPa winds from a) R2, b) CFSR, c) RSM-ROMS, and d) corresponding difference between RSM-ROMS and CFSR (c-b). The seasonal cycle of the $742925 \mathrm{hPa}$ winds for e) Caribbean LLJ Index (averaged over $12.5^{\circ} \mathrm{N}-17.5^{\circ} \mathrm{N}$ and $76^{\circ} \mathrm{W}-80^{\circ} \mathrm{W}$ ), f)

743 Panama LLJ Index (averaged over $3^{\circ} \mathrm{N}-8^{\circ} \mathrm{N}$ and $76^{\circ} \mathrm{W}-80^{\circ} \mathrm{W}$ ), g) Papagayo LLJ Index (averaged 744 over $11^{\circ} \mathrm{N}-14^{\circ} \mathrm{N}$ and $82^{\circ} \mathrm{W}-90^{\circ} \mathrm{W}$ ), and $\mathrm{h}$ ) Tehuantepec LLJ Index (averaged over $13^{\circ} \mathrm{N}-18^{\circ} \mathrm{N}$ 745 and $\left.94^{\circ} \mathrm{W}-96^{\circ} \mathrm{W}\right)$. The shaded values in $(\mathrm{a}-\mathrm{d})$ is the magnitude $\left(\mathrm{ms}^{-1}\right)$ of the wind vectors. 

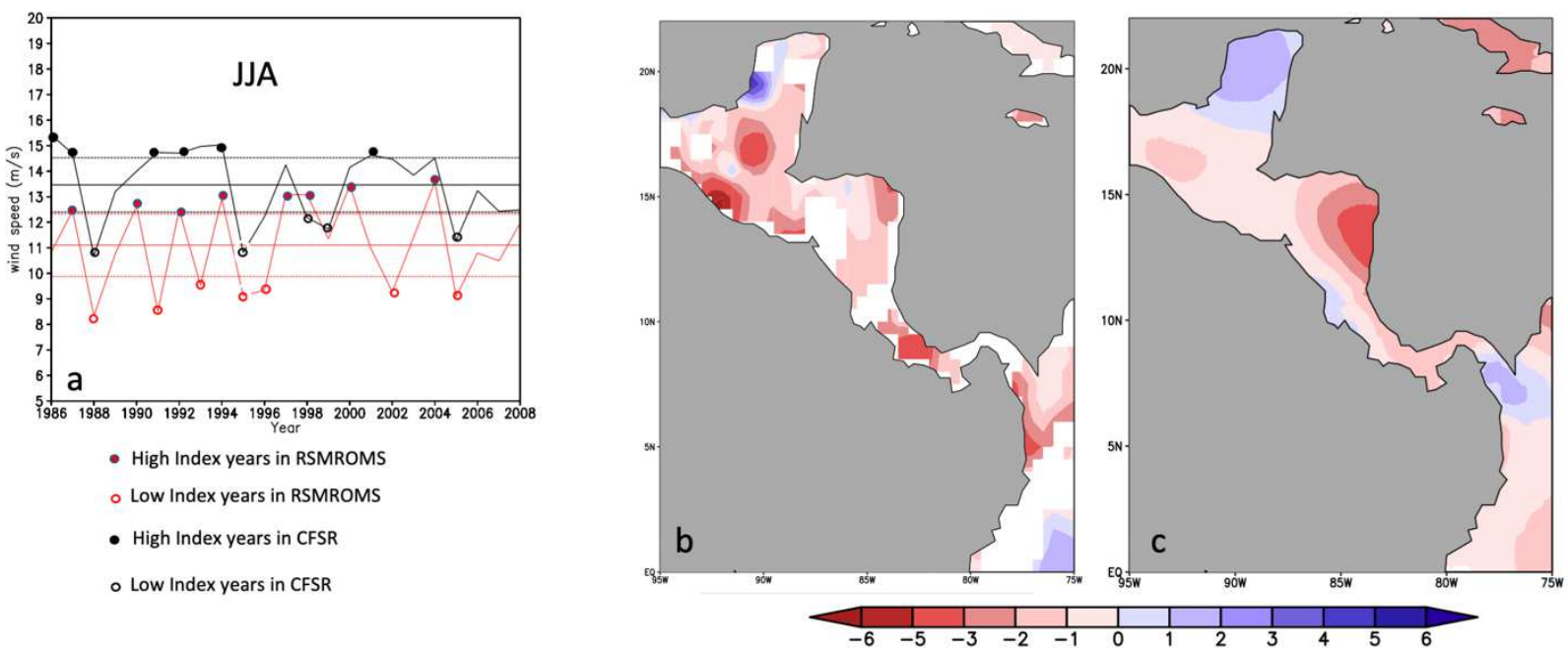

Figure 8: a) The Caribbean Low Level Jet (CLLJ) index for JJA from CFSR (black line) and RSMROMS (red line). The open and filled circles indicate high and low CLLJ index seasons. The solid horizontal lines are the corresponding mean of the CLLJ index from CFSR (black) and RSMROMS (red). The dotted horizontal lines on either side of the mean is (mean $\pm 0.75 \times$ standard deviation) of the CLLJ index from CFSR (black) and RSM-ROMS (red). The corresponding difference of seasonal mean rainfall $\left(\mathrm{mm} \mathrm{day}^{-1}\right)$ between high and low CLLJ index years for JJA from b) CPG and c) RSM-ROMS. Only significant values at 95\% confidence interval according to t-test in $(\mathrm{b}$, and $\mathrm{c})$ is plotted. 

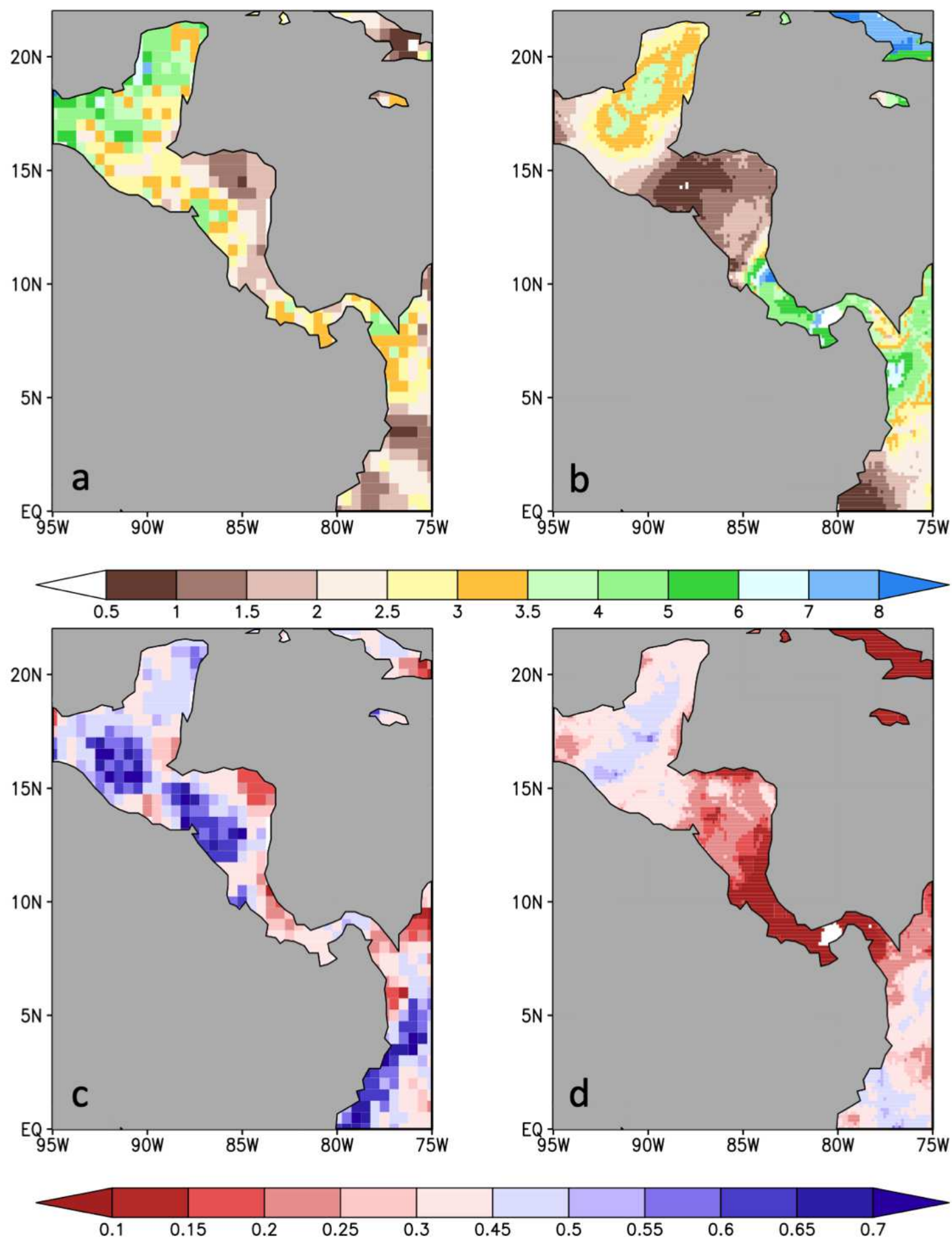

760 Figure 9: The $(\mathrm{a}, \mathrm{b})$ intensity $\left(\mathrm{I}\right.$; units: $\left.\mathrm{mm} \mathrm{day}^{-1}\right)$ and $(\mathrm{c}, \mathrm{d})$ frequency $(\mathrm{F}$; fraction of events in 25 761 years: 1986-2010) of the mid-summer drought events from (a, c) CPC and (b, d) RSM-ROMS 762 simulation. 

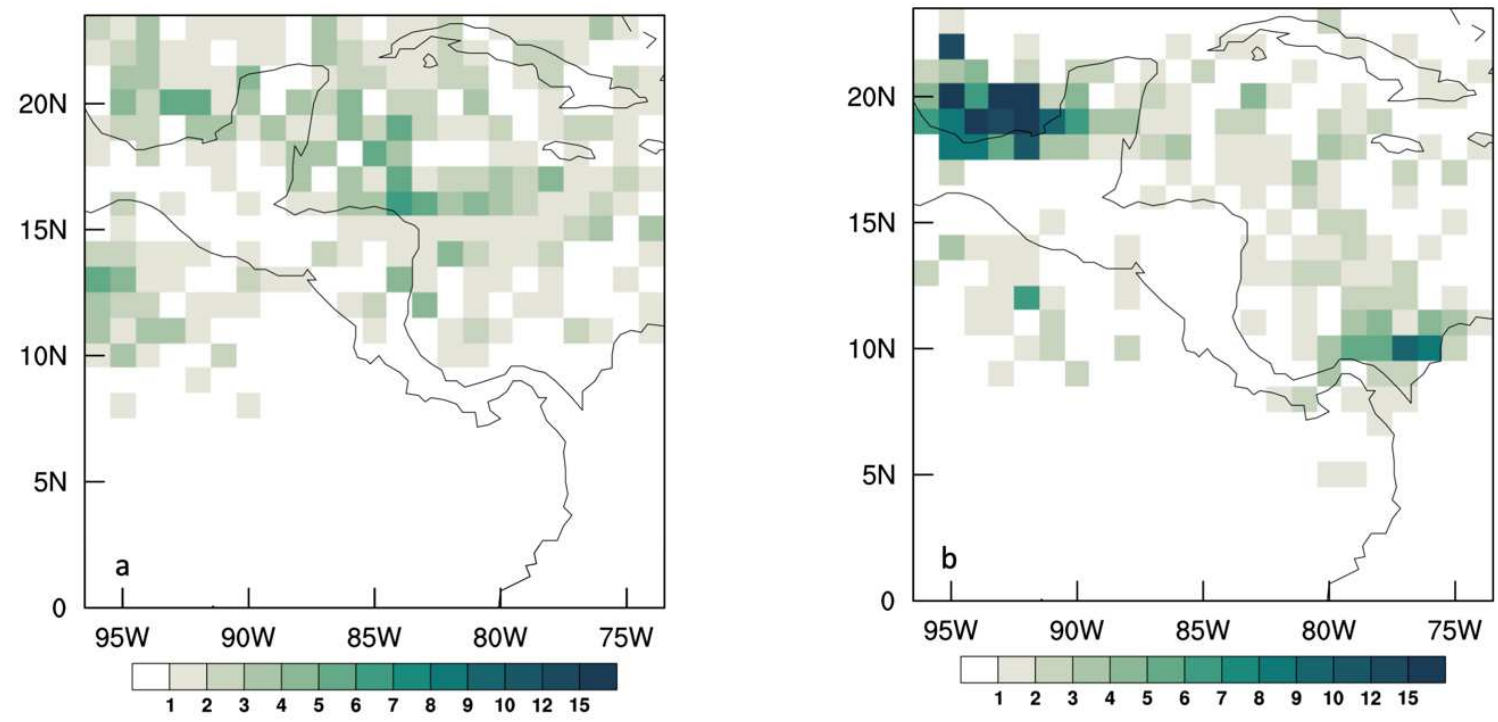

Figure 10: The track density plot of the TGs (i.e., number of TGs per $1^{\circ} \times 1^{\circ}$ ) from a) HURDAT2 and b) RSM-ROMS simulation over the time period of 1986-2010. It may be noted that the track density is based on once-a-day tracking data for both panels. The tracking algorithm used in (b) 


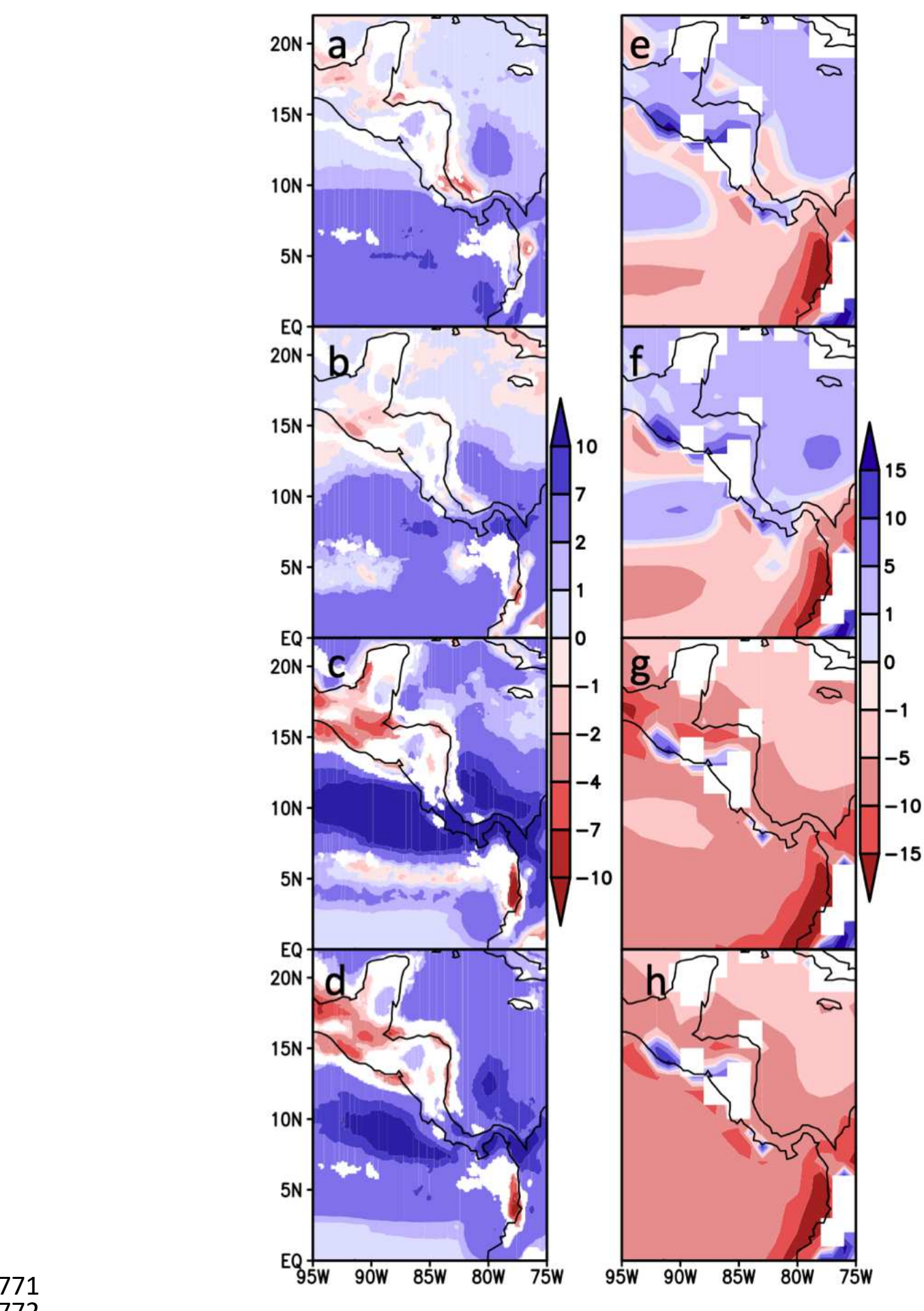

773 Figure 11: The seasonal mean climatological error of (a-d) rainfall ( $\left.\mathrm{mm} \mathrm{day}^{-1}\right)$ and $(\mathrm{e}-\mathrm{h})$ 774 precipitable water $\left(\mathrm{kgm}^{-2}\right)$ from R2 reanalysis used in the lateral boundary forcing of RSM-ROMS 775 for (a, e) DJF, (b, f) MAM, (c, g)JJA, and (d, h) SON. The observations for rainfall and precipitable 776 water is IMERG and NVAP, respectively. 

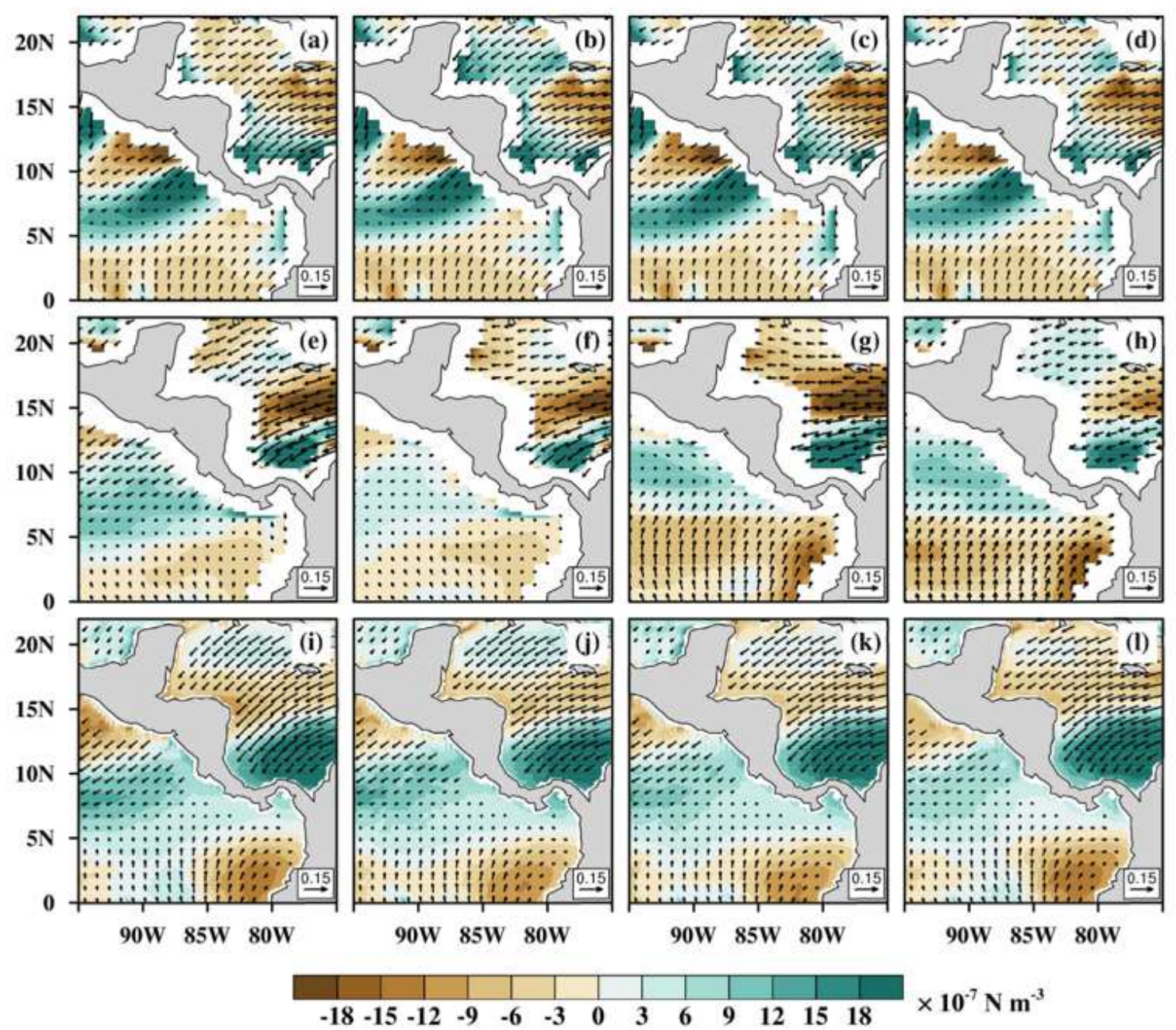

$\times 10^{-7} \mathrm{~N} \mathrm{~m}^{-3}$

780 Figure 12: The seasonal mean climatology of wind stress ( $\mathrm{Nm}^{-2}$; vectors) and the curl of the wind 781 stress ( $\mathrm{Nm}^{-3}$; shaded) from (a-d) observations, (e-h) R2 reanalysis, and (i-l) RSM-ROMS simulation 782 for (a, e, c) DJF, (b, f, j) MAM, (c, g, k) JJA, and (d, h, l) SON seasons. 